Cornell University Law School

Scholarship@Cornell Law: A Digital Repository

2012

Complexity, Innovation, and the Regulation of Modern Financial Markets

Dan Awrey

Follow this and additional works at: https://scholarship.law.cornell.edu/facpub

Part of the Banking and Finance Law Commons, and the Economic Theory Commons 


\title{
COMPLEXITY, INNOVATION, AND THE REGULATION OF MODERN FINANCIAL MARKETS
}

\author{
DAN AWrey*
}

The intellectual origins of the global financial crisis (GFC) can be traced back to blind spots emanating from within conventional financial theory. These blind spots are distorted reflections of the perfect market assumptions underpinning the canonical theories of financial economics: modern portfolio theory, the Modigliani and Miller capital structure irrelevancy principle, the capital asset pricing model and, perhaps most importantly, the efficient market hypothesis. In the decades leading up to the GFC, these assumptions were transformed from empirically (con)testable propositions into the central articles of faith of the ideology of modern finance: the foundations of a widely held belief in the selfcorrecting nature of markets and their consequent optimality as mechanisms for the allocation of society's resources. This ideology, in turn, exerted a profound influence on how we regulate financial markets and institutions.

The GFC has exposed the folly of this market fundamentalism as a driver of public policy. It has also exposed conventional financial theory as fundamentally incomplete. Perhaps most glaringly, conventional financial theory failed to adequately account for the complexity of modern financial markets and the nature and pace of financial innovation. Utilizing three case studies drawn from the world of over-the-counter (OTC) derivatives-securitization, synthetic exchange-traded funds and collateral swaps-the objective of this paper is thus to start us down the path toward a more robust understanding of complexity, financial innovation, and the regulatory challenges flowing from the interaction of these powerful market dynamics. This paper argues that while the embryonic post-crisis regulatory regimes governing OTC derivatives markets in the U.S. and Europe go some distance toward addressing the regulatory challenges stemming from complexity, they effectively disregard those generated by financial innovation.

\section{TABle of Contents}

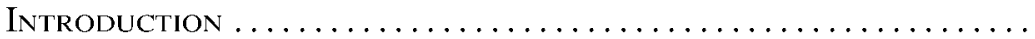

I. Toward a More Robust Theory of Complexity and its

Drivers ................................... 242

A. An Economic Framework for Understanding

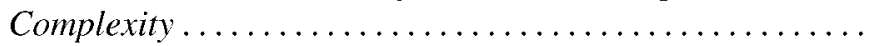

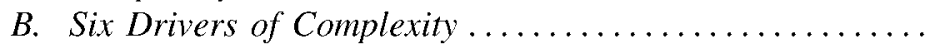

* University Lecturer in Law and Finance and Fellow, Linacre College, Oxford University. The author would like to thank John Armour, Blanaid Clarke, Merritt Fox, Anna Gelpern, Lawrence Glosten, Jeff Golden, Sean Griffith, Christian Johnson, Donald Langevoort, Katharina Pistor, Morgan Ricks, Colin Scott, Arthur Wilmarth, and Kristin van Zwieten for their extremely helpful comments and to the organizers and participants of workshops hosted by Harvard University, Oxford University, Fordham University, and University College Dublin for the opportunity to present previous drafts of this paper. The author would also like to acknowledge the generous support of both the Institute for New Economic Thinking and the Columbia University Global Finance and Law Initiative. 
II. THE CONVENTIONAL VIEW: Toward a Supply-Side Theory of Financial Innovation...................

A. Financial Innovation as a Demand-Side Response to

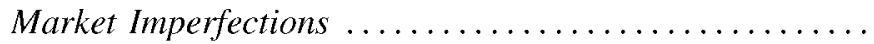

B. The Supply-side View: Financial Intermediaries as a Driver of Innovation . . . . . . . . . . . . . . . . . . . . .

III. The Relationship between Complexity and Financial

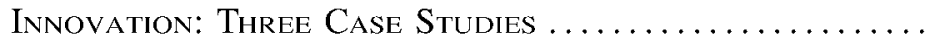

A. Complexity and Financial Innovation within OTC Derivatives Markets ............................

B. Three Case Studies in Complexity and Financial

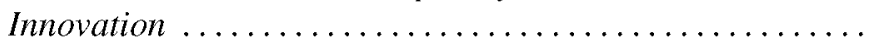

IV. Complexity and Financial Innovation: The Regulatory

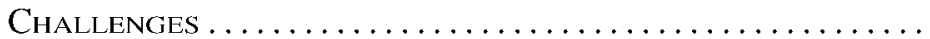

V. OtC Derivatives Regulation in the Wake of the GFC: A Brave New World ............................ 277

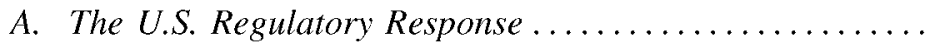
280

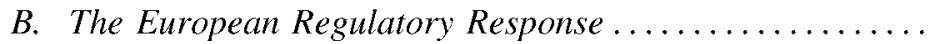
285

C. The Post-Crisis Regulatory Response: A Preliminary Assessment.............................. 288

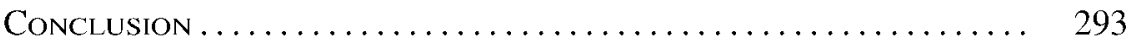

\section{INTRODUCTION}

The intellectual origins of the ongoing global financial crisis (GFC) can be traced back to shortcomings-blind spots-emanating from within conventional financial theory. These blind spots are distorted reflections of the perfect market assumptions underpinning the canonical theories of financial economics: modern portfolio theory (MPT), the Modigliani and Miller $(\mathrm{M} \& \mathrm{M})$ capital structure irrelevancy principle, the capital asset pricing model (CAPM) and, perhaps most importantly, the efficient market hypothesis $(\mathrm{EMH}){ }^{1}$ These theories share a common and highly stylized view of financial markets - one characterized by, inter alia, perfect information, the absence of transaction costs, and rational market participants. Yet in reality financial markets-and market participants-rarely (if ever) strictly conform to these assumptions. ${ }^{2,3}$ Information is costly and unevenly distributed,

\footnotetext{
${ }^{1}$ See discussion infra Parts I, II for greater detail on these theories, their centrality to the field of financial economics, and their underlying assumptions.

${ }^{2}$ The most notable exception arguably being public secondary markets for equity securities, where a significant body of empirical research exists to support the view that these markets generally conform to the assumptions of semi-strong form EMH. For a survey of this empirical work, see Burton Malkiel, The Efficient Market Hypothesis and Its Critics (Center for Econ. Policy Studies, Working Paper No. 91, 2003); Eugene Fama, Market Efficiency, Long-Term Returns and Behavioral Finance, 49 J. FIN. ECON. 283 (1998). Even in this context, however, it is still unrealistic - and, indeed, actually inconsistent with the operation of the arbitrage mechanism at the heart of conventional financial theory-to expect that markets will
} 
transaction costs are pervasive and often determinative, and market participants frequently exhibit cognitive biases and bounded rationality. ${ }^{4}$ Despite these seemingly uncontroversial observations, however, the empirically (con)testable assumptions of conventional financial theory have been transformed into the central articles of faith of the ideology of modern finance: the foundations of a widely held belief in the self-correcting nature of markets and their consequent optimality as mechanisms for the allocation of society's resources. ${ }^{5}$

The ideology of modern finance has exerted a profound influence on how we regulate financial markets and institutions. Perhaps most significantly, the pervasive belief in the social desirability of unfettered markets represented the driving force behind the sweeping agenda of financial deregulation witnessed in many jurisdictions in the decades leading up to the GFC. ${ }^{6}$ This market fundamentalism was grounded in the conviction that rational and fully informed market participants - utilizing sophisticated quantitative methods and the innovative financial instruments these methods made possible_-had effectively mastered risk. Public regulation, by implication, was largely relegated to a supporting role: namely, the provision of private property rights and efficient contract enforcement necessary to support private risk-taking. Ultimately, it was this market fundamentalism that justified turning a blind eye to the potential adverse effects of vast global current account imbalances, ${ }^{7}$ which acquiesced to the build-up of huge

always be in equilibrium. See Sanford Grossman \& Joseph Stiglitz, On the Impossibility of Informationally Efficient Markets, 70 AM. ECON. RгV. 393 (1980).

${ }^{3}$ As Ron Gilson has observed, it is not altogether clear whether the authors of these theories were initially attempting to describe real world financial markets or, alternatively, to provide the basis for a research agenda, which-by relaxing the perfect market assumptionscould enhance our understanding of how these markets work in practice. See Ronald J. Gilson, Market Efficiency After the Financial Crisis: It's Still a Matter of Information Costs 17 (May 2011 ) (unpublished manuscript) (on file with author). Ultimately, at least one of these authors did explicitly adopt the latter view. See Merton Miller, The Modigliani-Miller Propositions After Thirty Years, 2 J. Econ. Presspectives 99, 100 (1988).

${ }^{4}$ Observing this divergence between theory and reality, Fischer Black, the former M.I.T. finance professor, Goldman Sachs executive, and co-author of the Black-Scholes option pricing formula, once quipped that "Markets look a lot less efficient from the banks of the Hudson than from the banks of the Charles." Ptetre Brinsticin, Against The Gods: Thi: RimarkaBI.E STORY OF RISK 7 (1996).

5 See Simon Johnson \& James Kwak, 13 Bankers: The Wall Street Takeover and the Next Financial Meltidown 5, 104-09 (2010).

${ }^{6}$ See Fin. Crisis Inquiry Comm'n, Finat Ritort or the Nationat Commission on the Caustis of the Financial. Crisis in thi: Unititi Statis xviii (2011); Richard Posnir, A Fatiure of Caittailism: The Crisis of '08 and the Discint into Deprtssion (2009); George Cooper, The Origins of the Financinl Crisis: Central Banks, Credit Bubbles AND THI: EITICIIINT MARKTit FAI IACY (2008); Gilson, supra note 3, at 2-3; Johnson \& KW $\Lambda$, supra note 5, at 68-69. The term "deregulation" does not entirely capture the breadth or fundamental character of this trend. Indeed, it is perhaps more accurate to say that deregulation during this period was characterized by significant devolution of regulation from public to private actors and a non-interventionist stance toward the regulation of many financial markets and institutions that emerged, developed, and matured during this period.

${ }^{7}$ The influence of market fundamentalist thinking on the established wisdom underpinning the post-war push to liberalize international trade and capital flows is reflected in the 
amounts of risk within the so-called 'shadow banking' system ${ }^{8}$ and devolved significant responsibility for the design and implementation of capital adequacy standards to the very financial institutions that were ultimately subject to this micro-prudential regulation. ${ }^{9}$ At times, it appeared as if the only question to which 'more markets' was not the consensus answer was: where do we turn when markets fail?

The GFC has revealed the folly of market fundamentalism as a driver of public policy. It has also exposed conventional financial theory as fundamentally incomplete. Perhaps most glaringly, conventional financial theory failed to adequately account for both the complexity of modern financial markets and the nature and pace of financial innovation. From sub-prime mortgages, securitization and credit default swaps (CDS) to sophisticated quantitative models for measuring and managing risk, the footprints of complexity and innovation can be observed throughout modern financial markets - and, importantly, at almost every significant step along the road to the GFC. ${ }^{10}$ Complexity and innovation have combined to generate significant asymmetries of information and expertise within financial markets, thereby

comments of Stanley Fischer, former First Deputy Managing Director of the International Monetary Fund (IMF): "free capital movements facilitate a more efficient allocation of global savings, and help channel resources into their most productive uses, thus increasing economic growth and welfare." Stanley Fischer, Capital Account Liberalization and the Role of the IMF, Lecture Given at the International Monetary Fund Annual Meeting (Sept. 19, 1997), http:// www.imf.org/external/np/speeches/1997/091997.htm.

${ }^{8}$ The shadow banking system includes (1) non-bank financial institutions such as finance companies, structured investment vehicles, securities lenders, money market mutual funds, hedge funds, and U.S. government sponsored entities, and (2) financial instruments such as repurchase agreements, asset-backed securities, collateralized debt obligations, and other derivatives, insofar as these institutions and instruments perform economic functions (i.e., maturity, credit, and liquidity transformation) typically associated with more "traditional" banks. See Gary Gorton \& Andrew Metrick, Regulating the Shadow Banking System, Thг: Brookings INsT. (Fall 2010), http://www.brookings.edu/ /media/files/programs/es/bpea/2010_fall_bpea_

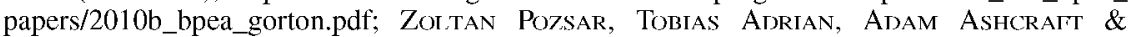

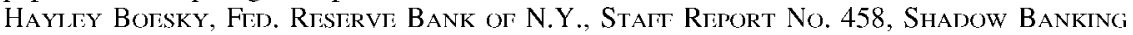
(2010).

${ }^{9}$ As most infamously epitomized by the ill-fated Consolidated Supervised Entity (CSE) Program administered by the U.S. Securities and Exchange Commission. See STC. ANT Exch. Comm'n, Ofticti of thi: Inspictor Gin., SEC's Ovirsight or Brar Strarns and Ret ated Entitits: The Consoimdited Suptrvistid Entity Program (2008), http://www.sec-oig.gov/ Reports/AuditsInspections/2008/446-b.pdf.

${ }^{10}$ And, indeed, the road to many previous financial crises. See, e.g., JoHN KenNETH G $\Lambda$ Lbraith, The Grent Crash of 1929 24-27, 51-55 (1955) (describing the role of financial innovations such as margin trading and so-called "investment trusts" in helping to fuel the speculative bubble that ultimately precipitated the 1929 U.S. stock market crash). More recent examples include both the role of portfolio insurance in the 1987 stock market crash and the role of high frequency traders, automated execution algorithms, and exchange traded funds in the so-called "flash crash" of May 6, 2010. See Presitjintiat. Task Force on Mkt. Mtichanisms, Riport of thi: Prisidintial. Task Force: on Markit Mischanisms: Submittid to The President of the United States, The Secretary of the Treasury, and The Chairman of the Federal Reserve Bonrd v (1988). See generally Staffs of the Commodity Futures Trading Comm'n and Sec. and Exch. Comm'n to the Joint Adjvisory Comm. on Emerging Regulatory Issues, Findings Regarding the Market Events of May 6, 2010 (2010). 
opening the door to suboptimal contracting and exacerbating already pervasive agency cost problems. ${ }^{11}$ At the same time, the pace of innovation has left financial regulators and regulation chronically behind the curve. Together, complexity and innovation thus give rise to a host of regulatory challenges, the full implications of which we are only just now beginning to understand.

Perhaps nowhere is the myopia of market fundamentalism more evident than in connection with the pre-crisis regulation of over-the-counter (OTC) derivatives markets. Over the course of the past three decades, these markets have grown from an obscure financial backwater into a global behemoth-the SUSD700 trillion gorilla of modern financial markets. Prevailing dogma prior to the GFC viewed the seemingly insatiable demand for many species of OTC derivatives as a rational response to market imperfections. Supply, in turn, was a rational response to this demand. That supply met demand within the marketplace was then generally interpreted as being dispositive of these instruments' private and social utility. This viewpoint was firmly rooted in the autonomous rational actor framework underpinning MPT, the M\&M capital structure irrelevancy principle, CAPM, and the EMH. Not coincidentally, conventional financial theory also provided the rationaleforcefully articulated by, among many others, U.S. Federal Reserve Board Chairman Alan Greenspan ${ }^{12}$ - for why public regulatory intervention was not necessary to ensure the safe and efficient operation of OTC derivatives markets. This stance was ostensibly bolstered by the emergence of private

${ }^{11}$ In the context of a principal-agent (or other cooperative) relationship between two or more parties, the term "agency costs" refers to costs incurred by the parties in connection with the monitoring and bonding of the other parties, along with any residual (hidden) losses stemming from the misalignment of incentives as between the parties. See Michael Jensen \& William Meckling, Theory of the Firm: Managerial Behavior, Agency Costs and Ownership Structure, 3 J. Fin. Econ. 305 (1976).

${ }^{12}$ Greenspan stated:

[P]rofessional counterparties to privately negotiated contracts also have demonstrated their ability to protect themselves from losses, from fraud, and counterparty insolvencies .... Aside from the safety and soundness regulation of derivatives dealers under the banking and securities laws, regulation of derivatives transactions that are privately negotiated by professionals is unnecessary. Regulation that serves no useful purpose hinders the efficiency of markets to enlarge standards of living.

The Regulation of OTC Derivatives: Hearings Before the H. Comm. on Banking and Financial Services, 105th Cong. (1998) (testimony of Alan Greenspan). See also Alan Greenspan, Technological Change and the Design of Bank Supervisory Policies, Remarks at the Conference on Bank Structure and Competition of the Federal Reserve Bank of Chicago (May 1, 1997), http:/ /fraser.stlouisfed.org/docs/historical/greenspan/Greenspan_19970501.pdf; Alan Greenspan, Government Regulation and Derivatives Contracts, Remarks to the Financial Markets Conference of the Federal Reserve Bank of Atlanta (Feb. 21, 1997), http://www.federalreserve.gov/ boarddocs/speeches/1997/19970221.htm; Press Release, U.S. Treasury Department, Joint Statement by Treasury Secretary Robert E. Rubin, Federal Reserve Board Chairman Alan Greenspan \& Securities and Exchange Commissioner Arthur Levitt (May 7, 1998), http:// www.treasury.gov/press-center/press-releases/Pages/rr2426.aspx; Lawrence Summers, Testimony Before the Senate Banking Committee (July 31, 1998), http://www.treasury.gov/presscenter/press-releases/Pages/rr2616.aspx. 
actors such as the International Swaps and Derivatives Association (ISDA), along with various trade execution, clearing, and settlement platforms, to provide the legal and operational infrastructure necessary to support the development and growth of these new markets. ${ }^{13}$

OTC derivatives markets epitomize both the complexity of modern financial markets and the nature and pace of innovation within them. For this reason, they offer us an illuminating window into the regulatory challenges generated by the interaction of these powerful (and yet poorly understood) market dynamics. Perhaps not surprisingly, these challenges ultimately stem from the availability and allocation of a single and immensely precious commodity: information. How costly is it to acquire? Who has it? And, importantly, who doesn' $t$ ? $^{14}$ As we shall see, the answers to these and other related questions are highly instructive in terms of how we should approach the regulation of OTC derivatives markets-and the broader financial systemgoing forward.

The objective of this paper is to start us down the path toward a more robust understanding of the regulatory challenges that flow from complexity and innovation within modern financial markets. It does not, however, seek to 'correct' the blind spots of conventional financial theory. This is an important point. What follows is not an indictment of the methodologies of positive economics from which the insights of conventional financial theory have largely derived. ${ }^{15}$ Indeed, the rigorous logic and hypothesis testing at the core of this discipline have contributed greatly to our understanding of the economic world. At the same time, however, it must be acknowledged that the intellectual tools of this discipline-and the assumptions upon which they are founded-have been (at best) misconstrued and (at worst) hijacked by those seeking to advance the cause of market fundamentalism. ${ }^{16}$

It is in response to this pyrrhic victory of rhetoric over reality that this paper seeks to establish a more stable and constructive equilibrium between financial theory and how we approach financial regulation. ${ }^{17}$ Just as market fundamentalism has been found wanting in the wake of the GFC, so too will any approach to regulation which favors ideological purity over the rigorous and ongoing evaluation of the market frictions and market failures that attract regulatory scrutiny and the anticipated costs and benefits of various

\footnotetext{
${ }^{13}$ See Dan Awrey, The Dynamics of OTC Derivatives Regulation: Bridging the PublicPrivate Divide, 11 Eur. Bus. Org. L. Rev. 155 (2010).

${ }^{14}$ And, indeed, if it can be acquired, manipulated, filtered, or analyzed within applicable temporal, cognitive, resource, or technological constraints.

${ }^{15}$ For a robust description (and defense) of these methodologies, see Milton Friedman, The Methodology of Positive Economics, in Essays in Posinive Economics (Milton Friedman ed., 1966).

${ }^{16}$ In this respect, it is irrelevant for the purposes of this paper whether policymakers were "true believers" in market fundamentalism or simply utilizing it for their own ends. What is important, rather, is that this ideology influenced (either directly or indirectly) how these policymakers approached the regulation of financial markets and institutions.

${ }_{17}$ Although certainly not a more static one.
} 
forms of regulatory intervention. ${ }^{18}$ Put somewhat differently, the only antidote to ideological fervor is the systematic study of how markets-and regulation-work in practice. ${ }^{19}$

One further point of clarification is perhaps in order. This paper is not an attempt to dissect the proximate or root causes of the GFC. Considerable scholarly ink has already been spilled on this subject and, even then, the debate over precisely what happened and why seems poised to rage on well into the new millennium. ${ }^{20}$ More importantly for the present purposes, however, while the crisis has undoubtedly served to bring these issues into sharper focus, the regulatory challenges generated by complexity and financial innovation existed prior to, and independently of, the events and circumstances which culminated in the GFC.

The remainder of this paper proceeds as follows. Part I begins by articulating a theoretical framework for understanding complexity that conceptualizes it as a function of two variables: information costs and bounded rationality. It then examines six key drivers of high information costs (and information failure) within modern financial markets and their points of intersection with the cognitive and temporal constraints on our ability to process information. ${ }^{21}$ Part II shifts the focus to financial innovation and advances a theory that re-conceptualizes it as a process of change-but not necessarily one of improvement-influenced by, inter alia, the supply-side incentives of the principal innovators: financial intermediaries. Part III then examines the multifaceted and mutually reinforcing relationship between complexity and financial innovation through the lens of three case studies drawn from the world of OTC derivatives: securitization, synthetic exchange-traded funds (ETFs) and collateral swaps. Leveraging these case studies, Part IV seeks to identify the regulatory challenges generated by the interaction of these powerful market dynamics. Part $\mathrm{V}$ then examines

\footnotetext{
${ }^{18}$ This paper thus adopts as its normative touchstone the evaluative framework provided by welfare economics, pursuant to which "optimal" or "efficient" markets or regulation are understood to be those which maximize net social welfare. Reflective of the real-world limitations facing policymakers, optimal or efficient regulation will be further understood to refer to that which maximizes net social welfare within resource and technological constraints-or, cloaked in the jargon of welfare economics, the tangency between the utility possibilities frontier and the highest attainable social welfare indifference curve (i.e. the "constrained blisspoint"). See Per-Olov Johnnsson, An Introduction to Momern Welfare Economics 28-29 (1991); Thi Niw Paigrave: Allocation, Intormation and Markits 1 (John Eatwell, Murray Milgate \& Peter Newman eds., 1989). For a more fulsome discussion of welfare economics and its utility (and limitations) in the domain of financial regulation, see Awrey, supra note 13, at 165-67.

${ }_{19}$ This approach is reflected in Ronald Coase's statement that "satisfactory views on policy can only come from a patient study of how, in practice, the market, firms, and government handle the problem of harmful effects." Ronald Coase, The Problem of Social Cost, 3 J.L. \& ECON. 1, 10 (1960)

${ }^{20}$ For a very useful synopsis of this literature, see Andrew Lo, Reading About the Financial Crisis: A 21-Book Review, 50 J. ECON. LITERATURe 151 (2012).

${ }^{21}$ These drivers include technology, opacity, interconnectedness, fragmentation, regulation, and reflexivity. See discussion infra Part II for greater detail.
} 
whether and to what extent the embryonic post-crisis regulatory regimes governing OTC derivatives markets in the U.S. and Europe effectively respond to these challenges and canvasses potential options for further reform. Part VI concludes.

As American essayist H.L. Mencken is purported to have observed: "for every complex problem there is an answer which is clear, simple and wrong." 22 Consistent with this axiom, this examination fails to generate an obvious or straightforward set of prescriptions. As in virtually all areas of public policy, tradeoffs abound. This paper concludes, therefore, by extracting and synthesizing the common themes flowing from this exploration of complexity and financial innovation. These themes underscore the importance and pervasiveness of information costs, asymmetries of information and agency cost problems within modern financial markets and, thus, the manifest need for mechanisms that (1) subsidize the production and dissemination of information and (2) align the incentives of both public and private actors with broader social welfare. They also highlight the nature and pace of change within modern financial markets and the resulting desirability of regulation designed and built with the objective of ensuring sufficient flexibility, responsiveness and durability. Viewed in this light, while this paper does not have in mind a specific destination, it can be understood as strongly advocating certain modes-and a general direction-of travel.

\section{Toward a More Robust Theory of Complexity AND its Drivers}

Modern financial markets are very, very complex. This complexity is compounded by the nature and pace of financial innovation. But what do we mean when we say that financial markets are 'complex' and 'innovative'? And what are the key drivers of complexity and innovation within modern financial markets? This section (and the next) sketch out preliminary-and at this stage largely theoretical-answers to these all-important questions.

\section{A. An Economic Framework for Understanding Complexity}

It is almost trite to observe that modern financial markets are "complex.' ${ }^{23}$ Curiously, however, scholars in the fields of both law and finance

\footnotetext{
${ }^{22}$ Regrettably, the author was unable to unearth the original source for this oft-cited quotation.

${ }^{23}$ For a small sampling of the legal academic work acknowledging the complexity of financial markets, see Steven Schwarcz, Regulating Complexity in Financial Markets, 87 WASH. L. REV. 211 (2009); Emilios Avgouleas, What Future for Disclosure as a Regulatory Technique? Lessons from the Global Financial Crisis and Beyond (Working Paper, 2009), available at http://papers.ssrn.com/sol3/papers.cfm?abstract_id=1369004; Gregory Krohn \& William Gruver, The Complexities of the Financial Turmoil of 2007 and 2008 (Working Paper, 2008), available at http://papers.ssrn.com/sol3/papers.cfm?abstract_id $=1282250$; Steven Schwarcz, Rethinking the Disclosure Paradigm in a World of Complexity, 2004 U. II.. L. Rev. 1 (2004).
} 
have expended relatively little time or effort attempting to understand this complexity or systematically identify its potential sources. ${ }^{24.25}$ So what makes modern financial markets complex? We can take our first tentative steps toward answering this question by constructing a simple (and hopefully intuitive) framework which conceptualizes complexity as a function of two variables. The first variable encompasses the costs incurred by actors in connection with searching for, acquiring, filtering, manipulating and analyzing information (i.e., information costs). The second variable, then, consists of, cognitive and temporal constraints on an actor's ability to process this information (i.e. bounded rationality). ${ }^{26}$ In many ways, this framework brings together, renders explicit, elaborates on, and formalizes intuitions pre-

\footnotetext{
${ }^{24}$ At least part of the explanation for this lack of attention likely stems from the fact that the theoretical and empirical literature examining MPT, the M\&M capital structure irrelevancy principle, CAPM, and the EHM has historically focused on the public markets for equity and, to a lesser extent, debt securities. In a recent review of the literature examining the EMH, for example, 53 of the 54 cited works were primarily or exclusively concerned with its application within the context of public equity markets. See Malkiel, supra note 2 . This of course makes perfect sense: these theories implicitly rely on the existence of the secondary market liquidity typically associated with public capital markets (in effect, to ensure the efficient operation of the arbitrage mechanism which moves markets toward equilibrium). What is more, it is the public nature of these markets that affords scholars access to the information necessary to measure how rapidly new information is impacted into security prices. Simultaneously, however, it must be acknowledged that this research strategy generates an inherently biased (and increasingly myopic) sample if one's ultimate objective is to measure the informational efficiency of modern financial markets. As we shall see, the vast majority of the complexity-and thus the information costs and bounded rationality - within modern financial markets does not emanate from within the relatively transparent (and static) public markets for capital.

${ }^{25}$ This is not to say, however, that scholars have not attempted to construct models designed to reflect the complex dynamics of modern financial markets. See, e.g., Robert May, Simon Levin \& George Sugihara, Ecology for Bankers, 451 NATURE 893 (2008); Robert May \& Nimalan Arinaminpathy, Systemic Risk: The Dynamics of Model Banking Systems, 46 J. Royat Soc. Intrineace 823 (2010); Prasanna Gai, Andrew Haldane \& Sujit Kapadia, Complexity, Concentration and Contagion, 58 J. Moneiary ECon. 453 (2011). Many of these models share a common methodology-first employed by Herbert Simon-which is, in effect, based on identifying similarities between financial systems, on the one hand, and physical, biological, or other social systems, on the other. See Herbert Simon, The Architecture of Complexity, 106 Proc. Am. Phil. Soc. 467 (1962). The obvious shortcoming of this methodology, however, is that while models drawn from other disciplines (and developed to analyze other subject matter) might mimic the complexity of financial markets (at a given moment of time), they fail to explain why financial markets are complex. This is the question at the heart of the present inquiry.

${ }^{26}$ Bounded rationality is a semi-strong form of rationality pursuant to which economic actors are assumed to be 'intendedly rational, but only limitedly so.' OLIVER WLLIAMSON, THE Economic Institutions or CaptTai ism 11 (1985) (quoting Hirkirit Simon, AddministraTiVe BeHAVior xxiv (1957)). The concept of bounded rationality is grounded in the notion that, if the mind is a scarce resource, there will exist cognitive and temporal constraints on our ability to process information. The sources and species of bounded rationality and related cognitive biases are themselves already the subject of a rich theoretical and experimental literature upon which the present inquiry does not attempt to build. For a survey of this literature, see Nicholas Barberis and Richard Thaler, "A Survey of Behavioral Finance" in George Constantinides, Milton Harris and René Stulz, (eds.), Handbook of the Economics of Finance (Elsevier, Amsterdam, 2003). See also, Daniel Kahneman, Thinking, Fast and Slow (Penguin, London, 2011).
} 
viously articulated by scholars such as Ron Gilson and Reinier Kraakman, ${ }^{27}$ Steven Schwarcz, ${ }^{28}$ Henry Hu, ${ }^{29}$ Gary Gorton, ${ }^{30}$ and Robert Bartlett. ${ }^{31}$

As a starting point, we can envision a perfectly rational and fully informed actor. This actor incurs no information costs and processes information completely free from the distortions of bounded rationality. In effect, the attributes of this hypothetical actor reflect the central assumptions of conventional financial theory. Simultaneously, we can envision a real world actor - be it a single individual or a group of individuals working together in a firm or other organization - attempting to understand a particular constellation of facts or state of the world: a 'snowball' interest rate swap; the balance sheet of a large, complex financial institution (LCFI), or the myriad of systemic interconnections between financial markets and institutions, for example. To fully understand this constellation of facts or state of the world, this real world actor must invest in the acquisition, filtering, manipulation and analysis of information. ${ }^{32}$ It may also exhibit some form and measure of bounded rationality. The difference between our hypothetical and real world actors can be understood in terms of their respective tolerances for complexity.

The first important insight we can draw from this framework is that an actor's tolerance for complexity is inherently relative. ${ }^{33}$ What one actor views as immediately comprehensible, another may view as too complex to understand. Thus, we can envision a second real world actor attempting to understand the same constellation of facts or state of the world, but facing a different quantum of information costs or measure (or kind) of bounded rationality. Ultimately, we would expect the differences between each actor's information costs and bounded rationality-i.e. their relative tolerances for complexity - to be a function of several variables. Variables specific to each actor might conceivably include, inter alia, economies of scale in the production or analysis of information; technological or resource constraints; and, importantly, the actor's initial position within the constellation of facts or state of the world in question. External variables, meanwhile, might include market structure, regulation, and other institutional features that subsidize (or impede) the free flow of information and thus level (or tilt) the informational playing field.

${ }^{27}$ See Ronald J. Gilson \& Reinier H. Kraakman, The Mechanisms of Market Efficiency, 70 VA. L. REv. 549 (1984); Ronald J. Gilson \& Reinier H. Kraakman, The Mechanisms of Market Efficiency Twenty Years Later: The Hindsight Bias, 46 CorP. L. Commintator 173 (2004).

${ }^{28}$ See supra note 23 for relevant work from Schwarcz.

${ }^{29}$ See Henry Hu, Misunderstood Derivatives: The Causes of Information Failure and the Promise of Regulatory Incrementalism, 102 YALE L.J. 1457 (1993).

${ }^{30}$ See Gary Gorton, The Panic of 2007, 20-34 (Yale Int'l Center for Fin., Working Paper No. 08-24, 2008), available at http://papers.ssrn.com/sol3/papers.cfm?abstract_id=1255362.

${ }^{31}$ See Robert Bartlett III, Inefficiencies in the Information Thicket: A Case Study of Derivatives Disclosures During the Financial Crisis, 36 J. Corp. L. 1 (2010).

32 And, where our actor is an organization, coordination costs.

${ }^{33}$ Unless, of course, we assume that all actors are perfectly rational and fully informed. 
We might thus predict, for example, that an LCFI acting as a market maker within an opaque, dealer-intermediated, quote-driven market might enjoy a higher tolerance for complexity in respect of that market than, say, a pension fund manager, a regulator, or a law professor perched high atop his ivory tower. Put differently, we would expect to observe clear hierarchies vis-à-vis different actors in terms of both access to information and the resources needed to effectively process it. As we shall see, such hierarchies abound within modern financial markets: hierarchies between market participants; between market participants and regulators and, indeed, even between regulators. Ultimately, this simple observation-essentially that complexity is a subjective phenomenon and that, as a result, different actors may find themselves asymmetrically exposed to its dangers and opportunities-helps explain the existence and potential value of financial intermediaries. As explored in greater detail below, it is also the source of many of the regulatory challenges stemming from the complexity of modern financial markets.

The second important insight we can draw from this framework is that our tolerance for complexity is not infinite. ${ }^{34}$ More specifically, we can envision a frontier beyond which the combination of high information costs and bounded rationality can be expected to render full comprehension impossible within a given timeframe. Beyond the complexity frontier, actors will be forced to employ heuristics as a second-best strategy for understanding a particular set of facts or state of the world. ${ }^{35}$ As we shall see, the mere acknowledgement that there may exist elements of the financial system which are so complex as to render full comprehension a practical impossibility has potentially profound regulatory implications.

\section{B. Six Drivers of Complexity}

Armed with this provisional framework for understanding complexity, we can embark on an examination of the sources (or drivers) of high information costs-and information failure-within financial markets and the points of intersection between these costs and our own bounded rationality. Predictably, complexity itself hampers our ability to construct anything resembling a complete account of these drivers or the various interactions between them. Nevertheless, taking a broad look across the financial system, it is possible to identify at least six - in many respects intertwined and over-

\footnotetext{
${ }^{34}$ Unless, once again, we assume that actors are perfectly rational and fully informed.

35 This is not to suggest, of course, that actors might not also elect to employ heuristics in less complex circumstances. Ultimately, we are all satisficers. There also exists a more fundamental question here, although one which resides beyond the scope of this thesis, as to how to conceptualize the behavior of market participants beyond the complexity frontier. Intuitively, the autonomous rational actor model upon which conventional financial theory tends to rely would seem to possess limited explanatory power beyond the point at which high information costs and bounded rationality combine to force the use of heuristics.
} 
lapping-sources of complexity: technology, opacity, interconnectedness, fragmentation, regulation and reflexivity.

As we shall see, these drivers of complexity can be broken down into three categories: those influencing our capacity to process information, those impacting the availability or intelligibility of the information itself and, finally, those accelerating the velocity of informational change. The lines of demarcation between each of these categories can perhaps be clarified by drawing an analogy with marksmanship. The first category - which includes both financial and information technology - can be understood as relating to both the quality of the rifle and the proficiency of the individual marksman. The second category, meanwhile, includes drivers that-like darkness, fog, foliage or distance-obscure the visibility of the target. Drivers falling into this category include technology (again), opacity, interconnectedness, fragmentation and regulation. Lastly, we must somehow account for the fact that the target itself may be in motion. Thus, we need a category and driverreflexivity - that reflects the inherent dynamism of modern financial markets. Ultimately, just as we would expect each of these factors to influence the accuracy of the marksman's shot, so too would we expect each driver of complexity to influence the extent to which, in practice, actors are able to understand various constellations of facts or states of the world.

\section{Technology}

There is little doubt that advances in information technology, telecommunications, and financial theory over the course of the past half century have made a positive (gross) contribution toward the informational efficiency of financial markets. ${ }^{36}$ Faster and more powerful computers have enabled market participants to employ sophisticated and data-intensive quantitative (i.e. statistical) techniques to calculate the value of financial assets with greater precision and to better understand and more effectively manage various risks. ${ }^{37} \mathrm{~A}$ revolution in telecommunications, meanwhile, has made possible the almost instantaneous transmission of information to every

\footnotetext{
${ }^{36}$ See Robert Merton, Financial Innovation and the Management and Regulation of Financial Institutions 6 (Nat'l Bureau of Econ. Research, Working Paper No. 5096, 1995), available at http://www.nber.org/papers/w5096.

${ }^{37}$ Powerful computers, for example, have made possible the use of "value-at-risk" (VaR) methodologies and portfolio stress testing to measure and manage the risk of institutional insolvency. See Scott Frame \& Lawrence White, Empirical Studies of Financial Innovation: Lots of Talk, Little Action?, 42 J. ECON. Literature 116, 120 (2004). See also Scott Frame \& Lawrence White, Technological Change, Financial Innovation, and Diffusion in Banking 20-21 (Fed. Reserve Bank of Atlanta, Working Paper No. 2009-10, 2009), available at http:// papers.ssrn.com/sol3/papers.cfm?abstract_id=1434235; Lawrence White, Technological Change, Financial Innovation, and Financial Regulation in the U.S.: The Challenges for Public Policy 7 (Wharton Fin. Inst Ctr., Working Paper No. 97-33, 1997), available at http:// papers.ssrn.com/sol3/papers.cfm?abstract_id $=8072$.
} 
corner of the globe. ${ }^{38}$ Finally, breakthroughs in financial theory-perhaps most notably the development of MPT, ${ }^{39}$ CAPM, ${ }^{40}$ the Black-Scholes option pricing model (Black-Scholes), ${ }^{41}$ and their respective progeny-have given birth to a universe of new financial instruments which have been credited with, among other contributions, enhancing price discovery, market liquidity, and systemic resilience. In short, there exists a strong prima facie argument that these technological advancements have combined to significantly lower information costs within modern financial markets.

Upon closer scrutiny, however, these technological advancements are also the source of potentially significant information costs. ${ }^{42}$ The origins of this informational dark side can be traced back to conceptual breakthroughs such as MPT, CAPM, and Black-Scholes, the resulting emergence of "financial science" 43 within the field of economics, and its subsequent rise to prominence within the theory and practice of modern finance. ${ }^{44}$ The sophisticated mathematical models residing at the core of this discipline render its theoretical underpinnings largely inaccessible to all but a relatively small

${ }^{38}$ Indeed, strong linkages between revolutions in telecommunications and finance are by no means a recent phenomenon. From the telegraph, consolidated ticker tape, and electronic fund transfer, to the fax, the internet, and the Blackberry, the evolution of finance is intricately intertwined with the evolution of how we communicate with one another. See generally Kenneth Garbade \& William Silber, Technology, Communication, and the Performance of Financial Markets, 33 J. FIN. 819 (1978).

${ }^{39}$ MPT flows from the premise that there is a tradeoff between risk and return. On the basis of certain assumptions, MPT prescribes, for a given level of risk (variance), how to select a portfolio with the highest possible return (or, conversely, for a given level of return, how to select a portfolio with the least risk). MPT thus makes possible the construction of an efficient frontier from which an investor can choose their desired portfolio on the basis of their individual risk preferences. One of the key insights of MPT is that an asset should not be selected on the basis of its individual risk-return characteristics, but rather with a view to the effect of its addition in terms of the overall risk-return characteristics of the investor's portfolio. See Harry Markowitz, Portfolio Selection, 7 J. Fin. 77 (1952); HArry MArkowitz, Portfolio SelecTION: ETTICITNT Divirsirtcation OF InVISTMINTS (1959).

${ }^{40} \mathrm{CAPM}$ is used to calculate the expected rate of return on an asset to be added to a diversified portfolio on the basis of (1) the risk free rate of return, (2) the sensitivity of the asset to non-diversifiable (systemic) risk, and (3) the expected market return. See William Sharpe, Capital Asset Prices: A Theory of Market Equilibrium Under Conditions of Risk, $19 \mathrm{~J}$. FIN. 425 (1964); J $\Lambda$ CK TREYNOR, Toward a Theory of Market Value of Risky Assets, in AsSEI Pricing and Portiolio Piriformance: Modids, Stratigy and Ptiriormance Metrics (Robert Korajczyk ed., 1999).

${ }^{41}$ Black-Scholes is used to calculate the exact theoretical price of a real option. See Fischer Black \& Myron Scholes, The Pricing of Options and Corporate Liabilities, 81 J. PoL. ECoN. 637 (1973). While the original Black-Scholes model technically applied to the valuation of European options (i.e., options exercisable only at maturity), its progeny have been adapted to value far more exotic instruments.

${ }^{42}$ This is not to suggest that these costs outweigh the informational benefits of these technological advancements. My point here is simply that the existence of these costs contributes, utilizing my definition, to the complexity of modern financial markets.

${ }^{43}$ See generally $\mathrm{Hu}$, supra note 29 . The discipline is now generally known as financial economics.

${ }^{44}$ For a historical survey of this rise, see generally Pistir BTiRnstrin, CAittat. Itjias: The Improbable OrIGins of Modern WhLl STREeT (1992); Robert Merton, Influence of Mathematical Models in Finance on Practice: Past, Present and Future, 347 PhI. Transactions Royal SOC'y LONION 451 (1994). 
handful of academic economists, along with the so-called "quants" employed by investment banks, hedge funds and other financial institutions. ${ }^{45}$ Even in practice, the utilization of these models contemplates both information-intensive quantitative processes and the formulation of subjective judgments on the basis of accumulated technical expertise and experience in order to generate important input variables. ${ }^{46}$ Developing a comprehensive understanding of financial theory and how to utilize these models in practice thus requires an enormous upfront investment in human capital. ${ }^{47}$ Accordingly, while advances in financial theory are largely responsible for laying the foundations of modern (and at times more informationally efficient) financial markets, they must simultaneously be viewed as a potentially significant driver of information costs and, thus, complexity. ${ }^{48}$

Advances in financial theory and information technology have further contributed to the complexity of modern financial markets by making possible the development and wide-spread use of new and increasingly sophisticated financial instruments. Specifically, the existence of relatively robust markets for instruments such as OTC swaps ${ }^{49}$, asset-backed securities (ABS),$^{50}$ and collateralized debt obligations $(\mathrm{CDOs})^{51}$ implicitly rely on two

${ }^{45}$ See Richard Whitley, The Transformation of Business Finance Into Financial Economics: The Roles of Academic Expansion and Changes in U.S. Capital Markets, 11 Accr., ORG. \& SoC'Y 171, 173 (1986); Hu, supra note 29, at 1470.

${ }_{46}$ The Black-Scholes option-pricing model is a good example. Prior to the development of Black-Scholes, market participants seeking to determine the value of an option faced a problem: namely, they were required to accurately predict, inter alia, the probability distribution of the possible prices for the underlying asset at maturity. See Hu, supra note 29, at 1468 (citing Siephen Figlewski, Theoretical Valuation Models, in Financial Options: Firom Theory to Pracrice (Stephen Figlewski, William Silber \& Marti Subrahmanyam eds., 1992)). Market participants were thus required to formulate subjective judgments about the state of future market conditions. A significant part of the (perceived) genius of Black-Scholes was that it enabled market participants to calculate the precise theoretical value of a European option without having to construct such a probability distribution. In reality, however, Black-Scholes simply substituted the need to predict future asset prices with the need to predict the future volatility of those prices.

${ }^{47}$ Furthermore, as illustrated below, the nature and pace of financial innovation operates so as to demand significant ongoing investment in order to preserve the value of this human capital.

${ }^{48}$ See $\mathrm{Hu}$, supra note 29 , at 1470.

4) A swap is a series of mutual forward obligations whereby two counterparties agree to periodically exchange (or "swap") cash flows over a specified period of time. The classic example of a swap is an interest rate swap pursuant to which one party-typically a borrower with fixed rate obligations-agrees to make payments at a fixed interest rate to a counterparty who in turn agrees to pay the borrower a variable (or "floating") rate. The fixed rate borrower receiving a floating rate thus stands to benefit from any subsequent increase in interest rates, whereas its counterparty receiving the fixed rate under the swap will benefit from any decline. The periodic payments due under a swap are calculated with reference to what is often referred to as a "notional amount." The resulting obligations are then typically netted out against one another such that only one counterparty is obligated to remit payment in any given period.

${ }^{50} \mathrm{An}$ ABS is a security the income stream from which is backed by a pool of (typically illiquid) underlying assets such as mortgages, automobile loans, credit card receivables, or student loans.

${ }^{51}$ A CDO is a type of ABS typically created to hold fixed income assets such as bonds, CDS, or frequently, other ABS. 
necessary, if not individually sufficient, conditions: (1) the development of rational models for determining their intrinsic value, and (2) the ability to meet the computational demands of these models within a timeframe which enables market participants to profit from their use. ${ }^{52}$ Financial theory satisfies the first condition, and advances in information technology satisfy the second.

The development of the "originate-and-distribute" 53 mortgage lending model provides an illustrative example. Recent years have witnessed the increasing use of computer-generated credit scoring tools to process residential mortgage applications. The sub-prime mortgage market in particular was (originally) predicated on the use of sophisticated quantitative tools to assist lenders in better managing their exposure to high-risk borrowers. ${ }^{54}$ The utilization of these tools served to enhance the transparency of mortgage underwriting standards, thereby facilitating the development of a deep secondary market for mortgages repackaged and distributed via the process of securitization. ${ }^{55}$ In very broad terms, securitization is a financing technique that transforms non-liquid assets such as mortgages and loan receivables into more readily alienable ABS (or $M B S$ in the case of $m$ ortgages). ${ }^{56}$ This is achieved by pooling assets together and then slicing, dicing, and reconstituting the associated cash flow rights into separate tranches. On the supply side, the design of these MBS - and especially the pricing of the tranchesis itself heavily reliant on, once again, sophisticated financial models and modern information technology. ${ }^{57}$ On the demand side, purchasers employ the same technologies to measure and manage the risks associated with hold-

\footnotetext{
${ }^{52}$ In the absence of the first condition, one would expect a wide divergence between bidask spreads, ultimately leading either to very thinly traded markets or complete market failure. In the absence of the second condition, one would expect the existence of substantial transaction costs to alter the economic incentives of potential market participants, ultimately with much the same effect. A third pre-condition for many instruments-and in particular OTC derivatives - was the development of standardized legal documentation. See Awrey, supra note 13 , at 163 .

${ }^{53}$ Or "originate-to-distribute," depending on your views respecting why financial intermediaries innovate. See infra Part III.

${ }^{54}$ See Frame \& White, Technological Change, supra note 37, at 6.

${ }^{55}$ See John Straka, A Shift in the Mortgage Landscape: The 1990s Move to Automated Credit Evaluations, 11 J. Hous. ResenrCh 207 (2000); Michael LaCour-Little, The Evolving Role of Technology in Mortgage Finance, 11 J. Hous. Rišarch 173 (2000); Susan Gates, Vanessa Perry \& Peter Zorn, Automated Underwriting in Mortgage Lending: Good News for the Underserved?, 13 Hous. PoL 'y Deвıте 369, 370, 389 (2002); Frame \& White, Technological Change, supra note 37, at 14-15.

${ }^{56}$ Among other implications, securitization has the effect of reducing (and potentially eliminating) lenders' exposure to borrower default. As a corollary, it also dilutes the incentives of lenders to screen for and monitor creditor and asset quality.

${ }^{57}$ See Frederic Mishkin, Financial Innovation and Current Trends in U.S. Financial Markets 8-9 (Nat'l Bureau of Econ. Research, Working Paper No. 3323, 1990), available at http:// www.nber.org/papers/w3323. See also Peter Tufano, Financial Innovation, in Handiook or The ECONOMics of Finance 321-22 (George Constantinides, Milton Harris \& René Stultz eds., 2003).
} 
ing these securities in their portfolios. ${ }^{58}$ At every stage of the process, financial theory and information technology combine to facilitate the development of new financial instruments and markets. While the acronyms may change, this same fundamental story can been observed playing out across modern financial markets.

So how have these developments combined to render financial markets more complex? In the wake of the GFC, it has been widely acknowledged that even the most (ostensibly) sophisticated counterparties failed to grasp the technical nuances of many of the new instruments and markets made possible by the confluence of advances in financial theory and information technology. ${ }^{59}$ Gary Gorton, for example, has observed that many market participants did not fully appreciate how the unique structure of sub-prime mortgages made the MBS and CDOs into which they were repackaged particularly sensitive to volatility in underlying home prices. ${ }^{61}$ Along a similar vein, Joshua Coval, Jakub Jurek, and Erik Stafford have demonstrated how ratings agencies and other market participants failed to perceive both (1) how the structure of CDOs (and CDO-squared ${ }^{61}$ ) amplified initial errors with respect to the calculation of default risk on underlying assets, and (2) the systematic interconnections between these assets. ${ }^{62}$ Advances in financial theory and information technology have, accordingly, proven themselves to be less than perfect tools for understanding the complex dynamics of the very instruments and markets that they have combined to make possible. ${ }^{63}$ Put simply, technology has been unable to keep pace with itself. The (net) contribution of technology toward the complexity of modern financial markets must ultimately be measured by the extent of this imperfection.

\footnotetext{
${ }^{58}$ David $\mathrm{Li}$, for example, developed a formula known as the Gaussian copula that became widely employed prior to the GFC to evaluate the relationships between the default risks associated with various assets held within securitization structures. See Felix Salmon, Recipe for Disaster: The Formula That Killed Wall Street, WILED, Feb. 23, 2009, at 1.

${ }^{59}$ See, e.g., Countrrparty Risk Mgimt. Policy Groud III, Containing Systemic Risk: The ROAd TO REFORM 53 (2008), available at http://www.crmpolicygroup.org/docs/CRMPGIII.pdf [hereinafter CRMPG III RгГORT] (observing that "there is almost universal agreement that, even with optimal disclosure in the underlying documentation, the characteristics of these instruments were not fully understood by many market participants").

${ }^{60}$ See Gorton, supra note 30, at 20-34. As Gorton explains, the unique structure of subprime mortgages (specifically their short duration, step-up rates, and pre-payment penalties) effectively provided lenders with an implicit embedded option on home prices.

${ }^{61}$ In broad terms, a CDO-squared is simply a CDO that has invested in securities issued by other CDOs.

${ }^{62}$ See Joshua Coval, Jakub Jurek \& Erik Stafford, The Economics of Structured Finance, 23 J. Econ. Perspectives 3 (2009).

${ }_{63}^{63}$ Indeed, many of these imperfections are attributable to the unrealistic assumptions (e.g. the existence of autonomous rational actors, perfect information, liquidity) underpinning many financial models-assumptions that, not coincidentally, largely mirror those of conventional financial theory.
} 


\section{Opacity}

A second significant driver of complexity is the opacity of many financial instruments, markets and institutions. There are in essence two species of opacity. The first stems from the simple non-availability of information within a particular segment of the marketplace. ${ }^{64}$ Markets exhibiting this form of opacity -in particular with respect to pricing information and the identity of counterparties-have historically included those for OTC swaps, ABS, CDOs and repurchase agreements (or "repos") ${ }^{65}$, along with so-called "dark pools." The most frequently cited example is perhaps the historical lack of transparency surrounding the investors, holdings, and trading strategies of hedge funds. ${ }^{67}$ Even traditional commercial banks, however, manifest opacity of this variety insofar as the marketplace does not generally possess the borrower or asset specific information needed to accurately determine the value of these banks' loan books and, accordingly, the enterprise value of the lenders themselves. ${ }^{68}$ Furthermore, while banks and other financial institutions can be expected to possess a reasonable amount of information regarding their own counterparties, one would at the same time expect a marked decline in the extent and quality of the information they possess in respect of their counterparties' counterparties (and so on down the counterparty daisy chain). Investors in ABS, CDOs and especially CDO-squared face an analogous challenge insofar as it is often not possible to penetrate the layers of securitization in order to evaluate the quality of the underlying assets. ${ }^{69}$ This

${ }^{64}$ That is, the non-availability of information to a particular subset of market participants (and, potentially, regulators).

${ }^{65}$ A repurchase agreement is essentially a sale of securities under an agreement by which equivalent securities are to be repurchased at a future date. The duration of these agreements vary from overnight to months or even years, with compensation paid to the seller either in the form of interest or as a mark-up incorporated into the repurchase price. The purchaser may also be required by the seller to post collateral. See GoOde on LeGal Problems of Credit and) STCuRITy 250 (Louise Gullifer ed., 2008).

${ }^{66}$ Dark pools are effectively private OTC trading platforms used to match orders internally (i.e., between clients of the same firm) and between institutional trading desks. See David Bogoslaw, Big Traders Dive Into Dark Pools, BusinessweEk, Oct. 3, 2007, available at http:// www.businessweek.com/investor/content/oct2007/pi2007102_394204.htm.

${ }^{67}$ See Hedge Funds, Systemic Risk, and the Financial Crisis of 2007-2008: Written Testimony Prepared for the H. Comm. on Oversight and Government Reform, 111 th Cong. (2008) (testimony of Andrew Lo), available at http://papers.ssrn.com/sol3/papers.cfm?abstract_id= 1301217; Willa Gibson, Is Hedge Fund Regulation Necessary?, 73 Tाмтा ए. L. Rnv. 681, 710 (2000).

${ }^{68}$ See Robert Bartlett III, Making Banks Transparent, 65 VAND. L. RIV. 293 (2012); Donald Morgan, Rating Banks: Risk and Uncertainty in an Opaque Industry, 92 Am. EcON. Rev. 874 (2002). But see Mark Flannery, Simon Kwan \& Mahendrarajah Nimalendran, Market Evidence on the Opaqueness of Banking Firms' Assets, 71 J. Fin. Econ. 419 (2004).

${ }^{69}$ See Gorton, supra note 30, at 45, 59. See also Howell Jackson, Loan Level Disclosure in Securitization Transactions: A Problem with Three Dimensions (Harvard Law School Public Law \& Legal Theory, Working Paper No. 10-40, 2010), available at http:/papers.ssrn.com/ sol3/papers.cfm?abstract_id $=1649657$. 
first species of opacity can thus be understood as giving rise to classic asymmetries of information.

The second species of opacity stems from the dense "information thicket" ${ }^{\text {"7) }}$ generated by the overwhelming volume of data swirling around within modern financial markets. This opacity is the product of information that, while publicly available in a strictly technical sense, is extremely (if not prohibitively) costly to acquire, filter, manipulate, or analyze. ${ }^{71}$ The balance sheets of LCFIs exemplify this form of opacity. The number of positions held by LCFIs, the technical sophistication of the financial instruments used to take these positions, and the intricate (and potentially contradictory) nature of the resulting market and counterparty exposures render it virtually impossible to construct - in a timely fashion - a comprehensive picture of the overall risk profile of these institutions. ${ }^{72},{ }^{73}$ Much of the explanation for the growth of this information thicket in recent years can once again be traced back to the development of new financial instruments. As described above, the computational demands associated with many of these instruments are exceedingly high. ${ }^{74}$ As explained by Robert Bartlett:

Valuing even a single CDO investment_let alone a portfolio of such investments-requires a multi-faceted analysis of a considerable amount of both legal and financial data, ranging from an estimation of the default and prepayment risks of hundreds (potentially thousands) of underlying assets, analysis of the particular overcollateralization and subordination provisions attached to particular tranches of CDO securities, and an assessment of potential counterparty risk of the CDO's various hedge counterparties. ${ }^{75}$

Furthermore, insofar as these instruments facilitate the reconstitution and redistribution of risk within the financial system (often via transactions within relatively opaque markets), they obscure the location, nature and extent of the ultimate exposures. ${ }^{76}$ Like the first species of opacity, the information

${ }^{70}$ See Bartlett, supra note 31.

${ }^{71}$ See Schwarcz, Regulating Complexity in Financial Markets, supra note 23, at 222.

${ }^{72}$ As arguably evidenced by the fact that, in retrospect, the pre-GFC CDS spreads on LCFIs reflected significant under-pricing of the default risks associated with these institutions (the primary counter-argument being that the low spreads reflected the so-called "too-big-toofail" subsidy). In fact, CDS spreads within the financial services sector suggested that risks were at historically low levels. See Fin. Sirrv. Auth., Thi: Turntir Revirw: A Rigulatory Response tO the Global BANKing Crisis 46 (2009), http://www.fsa.gov.uk/pubs/other/turner_review.pdf [hereinafter TuRNT:R Rnvinw].

${ }^{73}$ The information thicket surrounding LCFIs is exacerbated by the existence of the first species of opacity insofar as, for example, GAAP only mandates that positions be reported in the aggregate.

${ }^{74}$ See Schwarcz, Rethinking the Disclosure Paradigm in a World of Complexity, supra note 23, at 13; Gorton, supra note 30, at 48-49. See also Letter from Warren Buffet to Shareholders of Berkshire Hathaway 17 (May 2, 2009), http:/www.berkshirehathaway.com/letters/ 2008ltr.pdf; CRMPG III REPOR', supra note 59.

${ }^{75}$ Bartlett, supra note 31 , at 4.

${ }^{76}$ See Schwarcz, supra note 23 , at $10,13$. 
thicket manifests the potential to generate acute asymmetries of information. Unlike the first, however, this second species of opacity thus raises the additional and rather sobering prospect that information may become altogether "lost". 77

Robert Bartlett's event study involving Ambac Financial provides a compelling illustration of how the information thicket may result in the loss of information. ${ }^{78}$ Ambac was and is a large, publicly-listed monoline insurance company, which, prior to the GFC, was active in the business of insuring multi-sector CDOs. As a result of the confluence of (1) statutory accounting rules mandating disclosure by monoline insurers of their largest exposures, and (2) European regulatory requirements mandating disclosure of large volumes of legal and financial documentation in respect of insured CDOs, it is possible to construct a relatively complete picture of Ambac's exposures and, accordingly, its financial health. ${ }^{79}$ In 2008, a number of CDOs insured by Ambac experienced multi-notch credit rating downgrades. Bartlett's analysis of the abnormal returns surrounding the announcement of each of these downgrades revealed no significant reaction in Ambac's stock price, short-selling data or the CDS spreads on its senior debt securities. ${ }^{80}$ The subsequent disclosure of these downgrades within Ambac's quarterly earnings announcement, however, was associated with significant one-day abnormal returns. ${ }^{81}$ Bartlett attributes this inefficiency to the low salience of individual CDOs within Ambac's portfolio and the logistical challenges of processing CDO disclosures. ${ }^{82}$ In effect, however, the density of the information thicket overwhelmed the powerful incentives possessed by market participants to seek out and exploit such informational inefficiencies.

\section{Interconnectedness}

The ongoing process of market liberalization-aided by advances in telecommunications ${ }^{83}$ - has sparked a pronounced trend toward greater globalization and integration of financial markets and institutions. This process has generated complex linkages within and between these markets and institutions and, importantly, the real economies they support. Financial institutions are connected to one another via their (increasingly complex) counterparty arrangements. ${ }^{84}$ The balance sheets of these institutions, mean-

\footnotetext{
${ }^{77}$ In the sense of being unknown to anyone. Gorton, supra note 30 , at 45 .

${ }^{78}$ See Bartlett, supra note 31.

${ }^{79}$ See id. at $5,8-12$.

${ }^{80}$ See id. at $23-35$.

${ }^{81}$ See id. at 28 . Using a single factor market model, Bartlett reports a one-day abnormal return of negative $43 \%$.

${ }^{82}$ See id. at $1,7,48-49$.

83 See Mishkin, supra note 57, at 10.

${ }^{84}$ And, indeed, their counterparties' counterparty arrangements. See Ricardo Caballero \& Alp Simsek, Complexity and Financial Panics 2 (Nat'l Bureau of Econ. Research, Working Paper No. 14997, 2009), available at http://papers.ssrn.com/sol3/papers.cfm?abstract_id= 1414382. Furthermore, the widespread use of collateral in connection with many of these ar-
} 
while, are connected to markets-and via markets to the balance sheets of other financial institutions - through mark-to-market accounting methods. ${ }^{85}$ These balance sheet linkages in turn generate systemic feedback effects between asset values, leverage, and liquidity. ${ }^{86}$ At an even higher macro level, household savings patterns in $\mathrm{China}^{87}$ are linked to global asset values via the resulting demand for (primarily U.S.) government securities, the consequent reduction in yields on these securities, and the incorporation of these lower yields as a proxy for the real risk-free rate into the discount rates used in asset pricing models. ${ }^{88}$

These are but a small sampling of the myriad of intricate, constantly evolving and often undetected interconnections that shape modern financial markets. While we have arguably come some distance in identifying and understanding the dynamics of some of these interconnections, ${ }^{89}$ the acquisition, analysis and ongoing monitoring of markets and institutions that this entails comes at a high (informational) cost. Put differently, these interconnections make it more costly to identify and monitor potential sources of risk within the financial system. ${ }^{90}$ What is more, the sheer number of these linkages, their intricacy, and their rapid evolution suggest that our ability to

rangements can generate linkages between the relevant counterparties (and markets) and prices within the markets for the collateral assets. During the GFC, for example, decreases in the value of senior tranches of sub-prime MBS held as collateral in the repo market triggered what eventually became the complete paralysis of this market. See Zachary Gubler, Instruments, Institutions and The Modern Process of Financial Innovation, 36 DTI. J. CoRI'. L. 55, 82-83 (2011).

85 Mark-to-market or "fair value" accounting refers to the practice, reflected in Generally Accepted Accounting Principles (GAAP) and International Financial Reporting Standards (IFRS), of accounting for the value of an asset on the basis of its current market price, the market price of similar assets or, if neither is available, another metric of "fair" value.

${ }^{86}$ The basic (spiral) pattern of these effects can be summarized as follows: (1) rising asset values inflate bank balance sheets, allowing them to extend greater leverage, (2) the resulting expansion of credit stimulates demand for assets and liquidity, and (3) increased demand for assets and liquidity has the effect of inflating prices while simultaneously reducing the liquidity premium on the assets. These effects operate in reverse in an environment of falling asset prices. See Tobias Adrian \& Hyun Song Shin, Liquidity and Financial Cycles, Presentation to the 6th BIS Annual Conference (June 18-19, 2007), http://www.bis.org/events/brunnen07/ shinpres.pdf; Int'l Monetary Fund, Assessing the Systemic Implications of Financial Linkages, in Giobat, Financtai. Stabidty RTíoRt (2009), available at http:/www.imf.org/external/ pubs/ft/gfsr/2009/01/pdf/chap2.pdf.

${ }^{87}$ Or, more precisely, China's resulting current account surplus (combined with its managed exchange rate regime).

${ }^{88}$ See TuRnIR RrVII, supra note 72, at 11-13. This has a double-barreled effect in terms of stimulating demand: (1) lower yields on U.S. government securities reduce real interest rates (thereby making it cheaper to employ leverage to purchase assets) and (2) the incorporation of lower yields into discount rates reduces risk premiums (thereby making the assets themselves cheaper).

${ }^{89}$ For an overview of some of the tools used to evaluate systemic linkages within the financial system (including the network approach, co-risk models, distress dependence matrices and default intensity models), see Int'l Monetary Fund, supra note 86. For a critique of these tools, see Steven Schwarcz, Systemic Risk, 97 Gio. L.J. 193, 206 (2008).

${ }^{9}$ See Avgouleas, supra note 23, at 22. Indeed, as explored in greater detail infra Parts V $\&$ VI, OTC derivatives offer a compelling example of such interconnectedness and how costly it can be to monitor. 
identify and understand them will ultimately be constrained by bounded rationality. It is perhaps not surprising, therefore, that many of these interconnections are only revealed (or their importance fully understood) at the point at which they become channels for the transmission of financial shocks. Ultimately, interconnectedness represents a significant source of opacity-and thus complexity — within modern financial markets.

\section{Fragmentation}

One of the most striking features of many of the transactions that exemplify modern financial markets is the extent to which they result in the fragmentation of economic interests. The archetypal example of this is securitization. As Kate Judge explains, by repackaging underlying assets such as mortgages into $\mathrm{ABS}$, repackaging $\mathrm{ABS}$ into $\mathrm{CDOs}$, and $\mathrm{CDO}$ s into CDO-squared, securitization transforms what was initially, in many instances, a bilateral relationship into a complex web involving potentially hundreds of dispersed counterparties..$^{91}$ Judge has coined the term "fragmentation nodes" $" 92$ to describe this category of transactions. Each successive fragmentation node attenuates the informational and economic relationship between counterparties and the underlying assets in which they have, ultimately, invested. ${ }^{93}$ This attenuation has the double-barreled effect of (1) increasing information and coordination costs for counterparties and (2) diluting their incentives to coordinate their activities or invest in the acquisition of information. ${ }^{94}$ Like interconnectedness, fragmentation thus represents a potentially significant driver of opacity within modern financial markets. ${ }^{95}$

\section{Regulation}

The complexity of modern financial markets is further compounded by the complexity of the regulatory regimes that govern them. This regulatory complexity manifests both substantive and structural elements. Substantive regulatory complexity stems from what U.S. Senator Charles Schumer and New York Mayor Michael Bloomberg, speaking in reference to the U.S. regulatory landscape, have characterized as the "thicket of complicated rules," $"$ which have built up over time within many regulatory regimes. The recently enacted Dodd-Frank Wall Street Reform and Consumer Protection

\footnotetext{
${ }^{91}$ See Kate Judge, Fragmentation Nodes: A Study in Financial Innovation, Complexity and Systemic Risk, STANFORD L. Rev. 101, 104-05, 127, 139 (2011).

${ }^{2}$ See id. at 105

93 See id.

${ }^{94}$ See id. at 104.

95 See id. at 105.

96 McKinstiy \& Co., Sustaining Niw York's ant the US' Giobat. Financiat, Sirvictes LEADERSHIP ii (2007).
} 
Act, ${ }^{97}$ to take one example, runs to 848 pages, is estimated to require up to 243 new federal regulations, ${ }^{98}$ and is believed by many-no doubt speaking with a touch of hyperbole-to manifest a "trillion unintended consequences." ${ }^{99}$ This comes on top of the substantial pre-existing edifice of federal securities laws, regulations and jurisprudence governing U.S. financial markets. Synthesizing this regulation - to say nothing of staying abreast of new regulatory developments-represents no small challenge for either market participants or financial regulators.

Structural regulatory complexity, meanwhile, stems from the disconnect between the increasingly globalized and integrated structure of many financial markets and institutions, on the one hand, and the fragmentation exhibited within and between many regulatory regimes, on the other. ${ }^{100}$ In the U.S., for example, federal responsibility for financial regulation is currently divided between a cacophony of regulators including the Federal Reserve Board, Financial Stability Oversight Council (FSOC), Securities and Exchange Commission (SEC), Commodity Futures Trading Commission (CFTC), Federal Deposit Insurance Corporation (FDIC), Financial Industry Regulatory Authority (FINRA), Office of the Comptroller of the Currency (OCC), Federal Housing Financing Agency (FHFA), and Consumer Financial Protection Bureau (CFPB) ${ }^{101}$ A similar degree of regulatory fragmentation can be observed within the E.U., where the new European Systemic Risk Board, European Banking Authority, European Securities and Market Authority, and European Institutional and Occupational Pensions Authority must coordinate their activities both with each other and with national supervisors in each of the bloc's 27 member states. ${ }^{102}$ This regulatory fragmentation results in higher information costs for both market participants (seeking to understand and comply with regulation) and regulators (seeking to coordinate their activities). ${ }^{103}$ What is more, the inevitable gaps generated by this fragmentation open the door to regulatory arbitrage. ${ }^{104}$ As we shall see, these

${ }^{97}$ Dodd-Frank Wall Street Reform and Consumer Protection Act, Pub. L. No. 111-203, $\$ 971,124$ Stat. $1376(2010)$.

${ }^{98}$ This estimate was made by New York law firm Davis Polk \& Wardwell. The Uncertainty Principle, W $\mathrm{WLL}_{\mathrm{L}}$ S. J., July 14, 2010, at A18.

${ }^{99}$ A Trillion Unintended Consequences, WAI.I. ST. J., July 7, 2010, at A16.

${ }^{100}$ See Merton, supra note 36, at 31.

${ }^{101}$ Compounding this fragmentation, many segments of the U.S. financial services industry are also highly regulated at the state level.

${ }^{102}$ For an overview of the new structure of financial supervision in the E.U., see Financial Supervision, Eur. CoMm'N, http://ec.europa.eu/internal_market/finances/committees/index_en. htm (last visited Mar 30, 2012). See also Eilis Ferran, Understanding the New Institutional Architecture of E.U. Financial Market Supervision (Cambridge Univ. Legal Studies, Research Paper No. 29/2011, 2010), available at http://papers.ssrn.com/sol3/papers.cfm?abstract_id= 1701147.

${ }^{103}$ Dan Awrey, The FSA, Integrated Regulation and the Curious Case of OTC Derivatives, 13 U. PA. J. Bus. L. 101 (2010).

${ }^{104}$ See the discussion infra Part IV for greater detail. The term "regulatory arbitrage" refers to transactions or strategies designed to exploit gaps or differences within or between regulatory regimes, ultimately with the intention of either reducing costs or capturing profits. 
gaps can also provide the stimulus for financial innovation and, as a result, contribute still further to the complexity of modern financial markets.

\section{Reflexivity}

Complexity does not exist independently of the observer. ${ }^{105}$ It is observers, after all, who incur information costs and who are inevitably constrained by bounded rationality. Yet we are not simply passive observers within financial markets: we are participants. Economists develop theories of market behavior, which in turn influence the very behavior of market participants whom economists seek to understand. ${ }^{106}$ Asset values affect our perception of risk, which affects the availability of credit, which affects asset values. ${ }^{107}$ Regulators introduce rules designed to constrain the behavior of market participants, incentivizing market participants to find ways of circumventing these constraints, thereby necessitating further regulatory intervention. ${ }^{108}$ The interactions between the cognitive perceptions of market participants and regulators, the actions predicated on these perceptions, and the impact of these actions within markets, generate complex and often self-reinforcing feedback loops. George Soros has characterized the interference created by these feedback loops as "reflexivity." 109 As Soros explains:

In situations that have thinking participants, there is a two-way interaction between the participants' thinking and the situation in which they participate. On the one hand, participants seek to understand reality; on the other, they seek to bring about a desired outcome. The two functions work in opposite directions: in the cognitive function reality is the given; in the participating function, the participants' understanding is the constant. The two can interfere with each other by rendering what is supposed to be given, contingent. . . Reflexivity renders the participants' understanding imperfect. . . 10

Further explaining:

The imperfection I am concerned with arises because we are participants. When we act as outside observers we can make state-

See Frank Partnoy, Financial Derivatives and the Costs of Regulatory Arbitrage, 22 J. Corp. L. 211,211 n.1 (1997).

${ }^{105} \mathrm{~A}$ fact that is reflected in the framework for understanding complexity set out above.

106 See Donatd Mackinzin: An Engini, Not A Camira (2006).

${ }^{107}$ To clarify, asset values affect our perception of risk (and thus the availability of credit) primarily by impacting the value of the collateral pledged and received in connection with the extension of credit.

${ }^{108}$ Edward Kane has characterized this interaction as the "regulatory dialectic." Edward Kane, Technology and the Regulation of Financial Markets, in TECHNOLOGY AND THE REGULAtion or Financiat. Markits: Sicuritits, Futuris and Banking 187-93 (Anthony Saunders \& Lawrence White eds., 1986).

${ }^{109}$ Grorgi: Soros, The Aichtemy or Finance 2 (2003).

${ }^{110} \mathrm{Id}$. at 2 . 
ments that do or do not correspond to the facts without altering the facts; when we act as participants, our actions alter the situation we seek to understand. ${ }^{111}$

The incursion of information costs with a view to better understanding the complex dynamics of financial markets (whether in search of knowledge or profit or as a means of achieving regulatory ends) will thus invariably alter these dynamics, thereby demanding the incursion of further information costs. ${ }^{112}$ It is a game without an end. Furthermore, our location within the object of study-indeed, ultimately, as the object of study-would, intuitively, seem likely to magnify the extent of our bounded rationality. Accordingly, while many economists have tended to shy away from the utilization of concepts such as reflexivity, any systematic attempt to understand the drivers of complexity within modern financial markets must somehow account for this uniquely human element.

Technology, opacity, interconnectedness, fragmentation, regulation and reflexivity together generate significant information costs and set us on a collision course with our own bounded rationality. In the process, they drive financial markets toward - and potentially beyond - the complexity frontier: often leading these markets to function in very different ways from those posited by conventional financial theory. Indeed, this process is in many ways the defining feature of what I have characterized as modern financial markets. Yet this is only one half of the story. To more fully appreciate the regulatory challenges posed within modern financial markets we must also examine the unique nature of financial innovation and, ultimately, the important relationship between complexity and innovation. In many respects, this examination boils down to a single question: who benefits from the complexity of modern financial markets?

\section{Toward a Supply-Side Theory of Financial Innovation}

The word "innovation" brings to mind products and processes-the printing press, indoor plumbing, penicillin, the designated hitter, etc.which have unequivocally made the world a better place. Economists, however, employ the term in a somewhat more expansive (and, on the surface at least, less normative) fashion to describe unanticipated shocks to the economy. ${ }^{113}$ Yet beneath this veneer of academic objectivity there survives a marked tendency within the literature to view these unanticipated shocks as being more in the nature of "unforecastable improvements." 114 This view

\footnotetext{
${ }^{111}$ Id. (emphasis added).

${ }^{112}$ See Schwarcz, supra note 23, at 238. 57 , at 310 .

${ }^{113}$ Along with the responses of economic actors to these shocks. See Tufano, supra note

${ }^{114}$ Merton Miller, Financial Innovation: The Last 20 Years and the Next, 21 J. Fin. \& Quantitativi Anaiysis 459, 460 (1986) (emphasis added). See also Frame \& White, supra note 37 ("Profit-seeking enterprises and individuals are constantly seeking new and improved
} 
seems likely to have been influenced by Joseph Schumpeter's conception of innovation as the catalyst of the "Creative Destruction" that fuels growth within capitalist economies. ${ }^{115}$ As Schumpeter explains:

The fundamental impulse that sets and keeps the capitalist engine in motion comes from the new consumers, goods, the new methods of production or transportation, the new markets, the new forms of industrial organization that capitalist enterprise creates. ${ }^{116}$

\section{Continuing:}

The opening up of new markets, foreign and domestic, and the organizational development from the craft shop and factory to such concerns as U.S. Steel illustrate the same process of industrial mutation-if I may use the biological term-that incessantly revolutionizes the economic structure from within, incessantly destroying the old one, incessantly creating a new one. This process of Creative Destruction is the essential fact about capitalism. ${ }^{117}$

While Schumpeter himself may not necessarily have espoused this view, it is not difficult to see how one might interpret his analysis as equating innovation - in the form of new goods, methods of production or forms of industrial organization -with progress. Indeed, Schumpeter's utilization of biological terminology is evocative of a Darwinian survival of the fittest. As will soon become apparent, however, the welfare implications of financial innovation are not nearly so straightforward. ${ }^{118}$ This indeterminacy points to the desirability of a more cautious, less value-laden understanding of financial innovation as an ongoing process of experimentation whereby new institutions, instruments, techniques and markets are (or are perceived to be) created. ${ }^{119}$ Ultimately, framing our understanding of financial innovation as simply a process of (perceived) change - and not necessarily one of improvement-has profound implications in terms of the way we look at modern financial markets.

products, processes, and organizational structures that will reduce their costs of production, better satisfy customer demands, and yield greater profits . . . When successful, the result is an innovation." [emphasis added]); $i d$. ("We define financial innovation as something new that reduces costs, reduces risks, or provides an improved product/service/instrument that better satisfies financial system participants' demands."); Merton, supra note 36, at 6 ("Looking at financial innovations . . . one sees them as the force driving the global financial system towards its goal of greater economic efficiency.").

115 See Josiph Schumptitir, CaptTat.ism, Sociatism and Dimocracy 119 (1975).

${ }^{116} \mathrm{Id}$. at $82-83$.

${ }^{117} I d$. at 83 .

${ }^{118}$ See Robert Litan, In Defense of Much, But Not All, Financial Innovation, THE BrooKINGS INST. (Feb. 17, 2010), http://www.brookings.edu/papers/2010/0217_financial_innovation_litan.aspx; James Van Horne, Of Financial Innovations and Excesses, 40 J. FIN. 621 (1985); Tufano, supra note 57, at 327-29.

${ }^{119}$ See Tufano, supra note 57, at 309. See generally Gubler, supra note 84. 


\section{A. The Conventional View: Financial Innovation as a Demand-Side Response to Market Imperfections}

We know relatively little about what stimulates financial innovation. The dominant economic view, grounded in Proposition I of the M\&M capital structure irrelevancy principle, ${ }^{120}$ envisions financial innovation as a rational demand-side response to market imperfections. ${ }^{121}$ These imperfections-many of which are themselves the products of exogenous changes to the economic environment ${ }^{122}$-include, inter alia, regulation and taxes $^{123}$; incomplete markets ${ }^{124}$; transaction costs ${ }^{125}$; asymmetries of information and the ensuing agency costs ${ }^{126}$; and other inefficiencies that constrain the ability of market participants to maximize their utility functions. Following this view, these imperfections generate demand for financial innovations, which promise, among other things, greater choice, lower costs, enhanced liquidity and more effective risk management. ${ }^{127}$ Figure 1 depicts the relationship between issuers and investors in an M\&M world.

Viewed in this light, for example, the extreme interest rate volatility of the 1970 s and early 1980 s lead to innovations such as adjustable rate mortgages, variable-rate certificates of deposit, financial futures, and interest rate swaps. ${ }^{128}$ U.S. regulatory constraints on the remuneration arrangements, eligible investors, and trading strategies of registered investment companies

${ }^{120}$ The M\&M capital structure irrelevancy principle advances, on the basis of certain assumptions, that the value of a firm is independent of its capital structure (i.e., its mix of equity, debt, and other capital). See Franco Modigliani \& Merton Miller, The Cost of Capital, Corporation Finance and the Theory of Investment, 48 AM. ECON. REv. 261 (1958). The assumptions underlying the M\&M principle include, inter alia, the absence of (1) information costs (and thus asymmetries of information and agency cost problems), (2) bankruptcy costs, and (3) taxes. In a world where these assumptions held true, the M\&M principle would suggest that there should be no demand for financial innovation (at least in terms of security design).

${ }^{121}$ See Tufano, supra note 57, at 313-14. For more recent work in which the dominance of this demand-side view is evident, see generally Nicola Gennaioli, Andrei Shleifer \& Robert

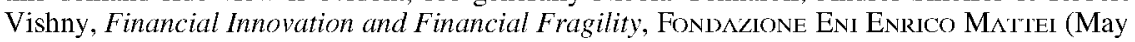
2010), http://www.feem.it/userfiles/attach/20109211528484NDL2010-114.pdf.

122 See Mishkin, supra note 57 , at 1.

${ }^{123}$ See, e.g., Frame \& White, supra note 37, at 9; Mishkin, supra note 57, at 11; Kane, supra note 108; Miller, supra note 114; Van Horne, supra note 118, at 623-24.

${ }^{124}$ See, e.g., Darrell Duffie \& Rohit Rahi, Financial Market Innovation and Security Design: An Introduction, 65 J. ECON. THEORY 1 (1985); Tufano, supra note 57, at 314; Van Horne, supra note 118

${ }^{125}$ See, e.g., Robert Merton, On the Application of the Continuous Time Theory of Finance to Financial Intermediation and Insurance, 14 Gintrya PAPtRs On Risk Ins. 225 (1989).

${ }^{126}$ See, e.g., Tufano, supra note 57 , at 315 . For a survey, see generally Milton Harris \& Artur Raviv, The Design of Securities, 24 J. Fin. Econ. 55 (1989); Franklin Allen \& Dougi.as Gai.j, Financiai. Innovation ant Risk Sharing 144-47 (1994).

${ }^{127}$ See e.g., Tufano, supra note 57, at 313-14 (citing Robert Merton, Operation AND)

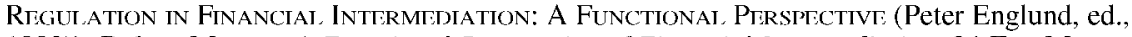
1993)); Robert Merton, A Functional Perspective of Financial Intermediation, 24 Fin. MGMT. 23 (1995); B ank ror Int'i. Stittijimints, Richint Innovations in Intirnationai. Banking (Apr. 1986), available at http://www.bis.org/publ/ecsc01a.pdf.

${ }^{128}$ See Hu, supra note 29, at 1466; Mishkin, supra note 57, at 2-5; Van Horne, supra note 118 , at $622-23$. 
and advisers spurred the development of hedge funds, and the thirst for yield on fixed income investments in the low interest rate environment of the 2000 s stimulated demand for, inter alia, new forms of CDOs and synthetic CDOs domiciled in tax efficient jurisdictions such as Ireland and the Cayman Islands. ${ }^{129}$

Figure 1: InNOvation in AN M\&M WORLD

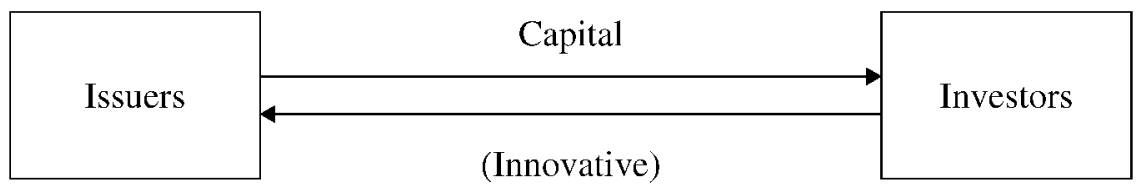

Economic Claims

However, while this demand-side story is important, it paints a fundamentally incomplete picture. First, it is deeply rooted in the Schumpeterian paradigm in which the intersection of supply and demand are too frequently viewed as being dispositive of an innovation's private and social utility. Second, and more importantly, it fails to adequately account for the incentives of the institutions at the center of the market for financial innovation: it ignores the role of financial intermediaries.

Figure 2: Innovation in a World with Financial Intermediaries

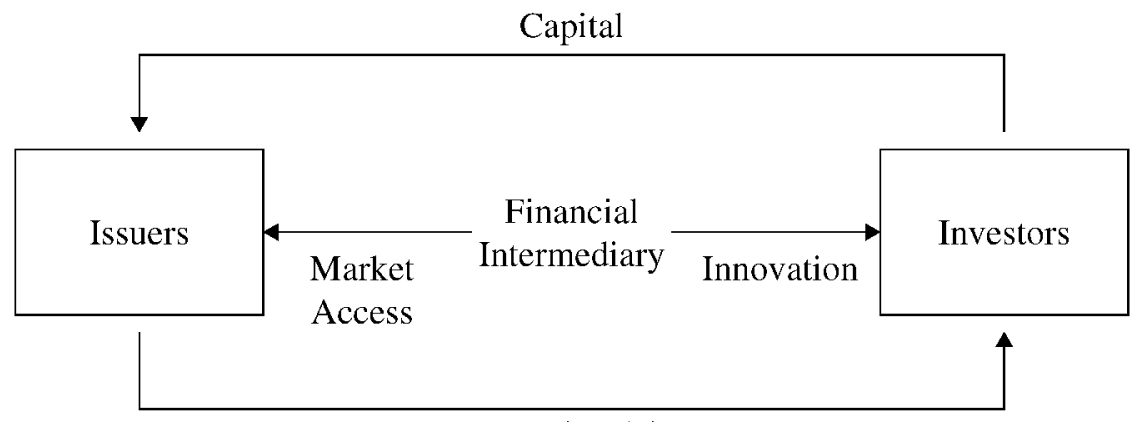

Economic Claims

${ }^{129}$ See Adair Turner, Chairman, Financial Services Authority, Speech at The Economist's Inaugural City Lecture: The Financial Crisis and the Future of Financial Regulation (Jan. 21, 2009), http://www.fsa.gov.uk/library/communication/speeches/2009/0121_at.shtml, explaining that a reduction in medium and long-term real risk free rates "had driven among investors a ferocious search for yield-a desire among any investor who wishes to invest in bond-like instruments to gain as much as possible spread above the risk-free rate, to offset at least partially the declining risk-free rate." 


\section{B. The Supply-side View: Financial Intermediaries as a Driver of Innovation}

Curiously, the supply-side dynamics of financial innovation have been largely overlooked by both academics and policymakers. So who are the primary suppliers of financial innovation and what are their incentives to innovate? The suppliers are, by and large, financial intermediaries such as commercial and investment banks, securities dealers, investment funds and insurance companies. At first glance, the incentives of these intermediaries might appear relatively straightforward: profit. ${ }^{130}$ In a competitive environment, however, one would expect these profits to rapidly erode as imitators enter the marketplace, attract market share and drive down margins. ${ }^{131}$ One would further expect the rate of this profit erosion-and thus the inclination of financial institutions to innovate-to be a function of the diffusion speed of the innovation.

We would thus expect the incentives of potential innovators to be relatively muted in the absence of some means of preventing imitators from freely appropriating the innovation. This is the traditional economic justification - articulated by Schumpeter and others-for the extension of intellectual property rights to innovators. ${ }^{132}$ By granting innovators a temporary monopoly on the fruits of their invention, these rights provide the economic incentives (i.e. rents) necessary to spur innovation. The problem, of course, is that intellectual property rights do not extend to the vast majority of financial innovations. ${ }^{133}$ JPMorgan cannot patent a CDO structure. ${ }^{134}$ Goldman

${ }^{130}$ See Mishkin, supra note 57 , at 1.

${ }^{131}$ See Van Horne, supra note 118 , at 622 . What little empirical evidence exists on this front (at least with respect to financial innovation) is inconclusive and not altogether relevant to the present inquiry. In a widely cited empirical study of financial innovations from 1976 to 1984, Peter Tufano found that financial intermediaries did not charge higher prices in the brief "monopoly" period before imitations appeared and, in the long-run, charged lower prices than rivals offering imitative products. Tufano did find, however, that innovating banks captured a larger share of underwriting business for the relevant products than did imitators. See Peter Tufano, Financial Innovation and First Mover Advantages, 25 J. Fin. ECoN. 213, 213 (1989). In a more recent study, Kenneth Carrow found an inverse relationship between the number of imitators and the size of underwriting spreads. See Kenneth Carrow, Evidence of Early Mover Advantages in Underwriting Spreads, 15 J. Fin. SERvices RES. 37, 37 (1999). Neither study, however, is particularly illuminating or immediately relevant insofar as (1) their research was focused exclusively on innovations within markets for publicly-traded securities and (2) neither researcher looked beyond underwriting spreads to examine other potential benefitsthe informational advantages associated with market-making or reputational effects, for example-derived from being an innovator.

${ }^{132}$ See, e.g., Kenneth Arrow, Economic Welfare and the Allocation of Resources for Invention, in The Rati: and Diriction or Invintive Activity: Economic ant Soctai. FacTORS (Nat'l Bureau of Econ. Research, ed., 1962); Avinash Dixit \& Joseph Stiglitz, Monopolistic Competition and Optimum Product Diversity, 67 Am. Econ. Rrv. 297 (1977); Jean Tirole, The Theory of Industrial Organization (1988).

${ }^{133}$ Outside the limited scope of business method patents. See State St. Bank v. Signature Fin., 149 F.3d 1368 (Fed. Cir. 1998). However, one would expect such patents to be of limited practical application in the context of financial innovation insofar as the application process contemplates public disclosure as a precondition to protection. More specifically, it is likely 
Sachs cannot copyright the acronym "CDS." It is perhaps unsurprising, therefore, that the diffusion rates of many financial innovations are exceptionally high. ${ }^{135}$ As a corollary, we would expect to observe relatively little innovation. Yet this is precisely the opposite of what we often see occurring within modern financial markets. This observation suggests that we need to develop a better understanding of why financial intermediaries innovate.

The key insight is derived from understanding that financial intermediaries possess at least three very different incentives to innovate. First, as previously acknowledged, they innovate in response to the emergence of 'genuine' demand within the marketplace. Second, they often possess their own incentives stemming from, for example, the desire to mitigate the impact of various regulatory requirements. A prime example of this, examined in greater detail in Part IV, is the use (and adaptation) of securitization techniques by banks to circumvent capital adequacy requirements. Third, financial intermediaries possess supply-side incentives to design and implement strategies with the intention of recreating the monopolistic conditions-usually afforded by the protection of intellectual property rights_which allow for the ongoing extraction of rents. There are at least two such strategies, and together, they help reveal the multifaceted relationship between complexity and financial innovation.

The first strategy involves artificially accelerating the pace of innovation. ${ }^{136}$ Financial intermediaries engage in this strategy for the purpose of achieving product differentiation ${ }^{137}$-not only vis-à-vis the innovations of their competitors but, crucially, between previous generations of their own innovations. In this respect, this strategy is broadly analogous to the shortterm "planned obsolescence" through innovation observed within, inter alia, the fashion, consumer electronics, software, and academic textbook industries. ${ }^{138}$ This strategy does not necessarily rely on the existence of any

that financial intermediaries will in many instances find such disclosure unpalatable for strategic reasons. This intuition finds empirical support in the form of studies finding that the decision in State Street did not have an appreciable impact on the number of patent applications filed by financial firms. See generally Robert Hunt, Business Method Patents and U.S. Financial Services (Fed. Reserve Bank of Philadelphia, Working Paper No. 08-10, 2008), available at http://www.philadelphiafed.org/research-and-data/publications/working-papers/2008/wp0810.pdf; see also Steven Pokotilow \& Ian DiBernardo, Protection for Financial Indices, ETFs and Other Products, 263 N.Y. L.J. (2006), for a discussion of the limits on intellectual property rights in financial indices and ETFs in the U.S.

${ }^{134}$ For an inside look at the development of CDOs by JPMorgan Chase \& Co., see generally Git.tian Tett, Fool's Gold: How the Botd Drtam or a Smat. Tribe at J.P. Morgan Was Corruptis by Wail. Stritit Gridid and Uni.jashitd a Catastrophi: (2009).

135 See Hu, supra note 29 , at 1484 . Although, as we shall see, this diffusion is in many cases limited to a relatively small group of financial intermediaries.

${ }^{136}$ See id. at 1479; Henry Hu, New Financial Products, the Modern Process of Financial Innovation, and the Puzzle of Shareholder Welfare, 69 TEx. L. REv. 1273, 1275 (1991).

${ }^{137}$ See Tufano, supra note 57, at 309.

${ }^{138}$ Very briefly, planned obsolescence is a strategy pursuant to which producers intentionally design products that are no longer functional or fashionable beyond a certain limited period of time. For a timely real world example of this strategy, readers might look to Apple's relatively frequent releases of new versions of its iPhone and iPad products (and, concomi- 
natural demand in the marketplace, nor on the innovation itself being "new" in any material respect. Rather, it can theoretically be premised on little more than, for example, capitalizing on investor short-termism, other behavioral factors, or simply tapping the instinctive human desire for the "next new thing." 139 The practical effect of this strategy is to reset the diffusion clock $^{140}$ - in essence creating more (albeit shorter) monopoly-like periodsthereby enabling intermediaries to extract greater rents from their innovations. ${ }^{141}$ Importantly, this strategy also manifests the potential to generate what U.K. FSA Chairman Adair Turner has characterized as "socially useless" "142 over-innovation.

The second strategy employed by financial intermediaries in response to the appropriability problem is to embrace complexity as an integral component of their business models. More specifically, many financial intermediaries have harnessed technology (and especially financial theory) to develop-and move an increasingly large proportion of their business activities into-new and relatively opaque institutions, instruments and markets. ${ }^{143}$ They have also lobbied fiercely against regulatory reforms, which would seek to achieve, among other objectives, a leveling of the informational playing field. ${ }^{144}$ Interestingly, this confluence of technology and opacity has not necessarily been utilized, as one might predict, to thwart imitators and thereby slow the diffusion rate of innovation. ${ }^{145}$ Indeed, small groups of financial intermediaries have often collaborated in the development of new

tantly, the overwhelming demand for these products even among customers owning previous generations of them). See generally Drew Fudenberg \& Jean Tirole, Upgrades, Tradeins and Buybacks, 29 RAND J. ECon. 235 (1998); Michael Waldman, Planned Obsolescence and the $R \& D$ Decision, 27 RANI J. Econ. 583 (1996); Michael Waldman, A New Perspective on Planned Obsolescence, 108 Q. J. Econ. 273 (1993). See also Glenn Ellison \& Drew Fudenberg, The Neo-Luddite's Lament: Excessive Upgrades in the Software Industry, 31 RanD J. ECon. 253 (2000); Laurence Miller, Jr., On Killing Off the Market for Used Textbooks and the Relationship Between Markets for New and Secondhand Goods, 82 J. Por. Econ. 612 (1974).

${ }^{139}$ See Van Horne, supra note 118 , at 626 . Or, in the case of academic textbooks, having a captive audience.

${ }^{140}$ Who, after all, would want to imitate previous innovations now viewed as being outmoded?

${ }^{141}$ Primarily in the form of higher underwriting spreads.

${ }^{142}$ Phillip Inman, Financial Services Authority Chairman Backs Tax on "Socially Useless" Banks, GuArdian (Aug. 27, 2009), http://www.guardian.co.uk/business/2009/aug/27/fsa-bonus-city-banks-tax.

${ }^{143}$ This of course makes perfect sense given the expectation of higher profit margins within such markets.

${ }^{144}$ See Gary Rivlin, The Billion Dollar Bank Heist, DaII Y B:AST (July 11, 2011), http:// www.thedailybeast.com/newsweek/2011/07/10/the-billion-dollar-bank-heist.html; Edwar Wyatt \& Eric Lichtblau, A Finance Overhaul Fight Draws a Swarm of Lobbyists, N.Y. Timrs, Apr. 19, 2010, at A1; Brady Dennis \& Steven Mufson, Bankers Lobby Against Financial Regulatory Overhaul, WAsh. Post. Mar. 19, 2010, http://www.washingtonpost.com/wp-dyn/ content/article/2010/03/18/AR2010031805370.html.

145 The most notable exception to this likely being a financial institution's investment strategies, where opacity is employed specifically with a view to preventing imitation. 
financial instruments, markets, and institutions. ${ }^{146}$ The resulting complexity has instead often been used by intermediaries as a group to prevent the commoditization of many financial innovations, ultimately forestalling the redistribution of rents from innovators to consumers which one might otherwise expect to take place over time. ${ }^{147}$ Within more arcane and opaque markets, these rents flow not only from higher underwriting spreads but also the informational advantages derived from the role financial intermediaries play as market-makers. ${ }^{148}$ It is in their quest to maximize and exploit their comparative informational advantage that financial intermediaries have thus driven us toward-and beyond-the complexity frontier.

This, of course, begs an important question: why would consumers of financial innovation-upon learning of the existence and potential use of these strategies-not take appropriate countermeasures? More specifically, why would rational and fully informed consumers not (1) apply a "lemons" discount, (2) insist on the utilization of costly contracting mechanisms designed to reveal information about the quality of the innovation, or (3) refuse to transact with financial intermediaries which they suspected of engaging in these strategies? ${ }^{149}$ As a preliminary matter, one might observe that these consumers' lower tolerance for complexity would impede this learning process. ${ }^{150}$ However, while this would almost certainly be true on one level, the relevant question simply becomes: why would consumers-or competing financial intermediaries - with a higher tolerance for complexity not share the fruits of their knowledge with less sophisticated consumers? Why, in other words, would this information not ultimately find its way into the broader marketplace?

There are a number of potential explanations for this type of market failure. A model developed by Xavier Gabaix and David Laisbon, for example, demonstrates how "shrouding" - the process by which producers hide information from consumers respecting high priced add-ons-can flourish even in highly competitive markets. ${ }^{151}$ Gabaix and Laisbon's model proceeds on the basis of a distinction between "sophisticated" and "myopic" con-

${ }^{146}$ See generally Awrey, supra note 13 , for an exploration of how financial intermediaries and other private actors-and ISDA in particular-have collaborated in the development of OTC derivatives markets.

${ }^{147}$ And, simultaneously, preventing a potentially costly innovation "arms race" between competing financial intermediaries.

${ }^{148}$ Including, inter alia, (1) pricing and counterparty information and (2) lower search costs for underwriting opportunities. See infra Part IV for a discussion of the market-making role played by financial intermediaries within OTC derivatives markets.

${ }^{149}$ Ultimately dis-incentivizing their use. For a theoretical discussion of the so-called "lemons" (i.e., adverse selection) problem, see George Akerlof, The Market for Lemons, 84 Q. J. ECON. 488 (1970).

${ }^{150}$ Indeed, one would expect that artificially accelerating the pace of innovation would itself impede this process.

${ }^{151}$ See Xavier Gabaix \& David Laibson, Shrouded Attributes, Consumer Myopia, and Information Suppression in Competitive Markets, 121 Q. J. ECoN. 505 (2006). 
sumers. ${ }^{152}$ Using examples drawn from the banking, ${ }^{153}$ hospitality, ${ }^{154}$ and office product industries, ${ }^{155}$ Gabaix and Laisbon then illustrate how producers utilize marketing strategies that obscure high-priced add-ons (often in the "fine print") with the objective of exploiting myopic customers who, by definition, fail to recognize that the proverbial wool is being pulled over their eyes. Sophisticated customers - who can see through the shroudingthen exploit the marketing schemes designed to target myopic customers by, for example, opting out of the add-ons. The result is an equilibrium in which producers, competitors offering close substitutes, ${ }^{156}$ and sophisticated consumers ${ }^{157}$ have no incentive to "de-bias" myopic customers by revealing the existence or true cost of the add-ons. ${ }^{158}$ Gabaix and Laisbon further observe that, over the long run, shrouding may be sustained by, inter alia, the entrance of new myopic customers; the development of new shrouding techniques, or importantly, new rounds of innovation. ${ }^{159}$

Second, even where these strategies are transparent to the marketplace, there remains the fundamental issue of market access. For example, as we will examine in greater detail in Part IV, the dealer intermediated structure of OTC derivatives markets - combined with the economies of scale associated with market making ${ }^{160}$ _has resulted in the concentration of trading activity within a small oligopoly of financial intermediaries. What is more, virtually all of these intermediaries are LCFIs. Market participants looking to utilize OTC derivatives have thus historically enjoyed a limited menu of counterparty options outside these powerful and opaque institutions. This in turn is likely to have diluted the impact of any market discipline that might have otherwise been brought to bear on those intermediaries who engage in strategies designed to extract rents from their higher tolerance for complexity.

All of this is not to suggest that this nascent supply-side theory of financial innovation fully encapsulates the incentives-or explains the behavior-of all financial intermediaries, in all markets, at all times. Demand-side factors are clearly important. Nor am I suggesting that financial in-

\footnotetext{
${ }^{152}$ And the existence of both in the marketplace. See $i d$. at 510.

${ }^{153}$ Where various ATM, minimum balance , and other fees are often shrouded. See $i d$. at 506.

${ }^{154}$ Where hotels, for example, shroud add-ons such as parking, telecommunications and room service charges. See id. at 507-08.

${ }^{155}$ Where printer manufacturers, for example, often advertise low prices for inkjet printers, but not the (far higher) cost of patented ink cartridges. See id. at 506.

${ }^{156}$ Who risk de-biasing their own consumers.

${ }^{157}$ Who can be understood as receiving a subsidy from the marketing strategies designed to exploit myopic consumers. See Gabaix \& Laibson, supra note 151, at 509-10.

${ }^{158}$ See id.

${ }^{159}$ See id. at 522-23.

${ }^{160}$ More specifically: (1) the informational benefits derived from access to a larger proportion of overall trading activity (i.e. deal flow) and (2) the hedging benefits derived from being able to trade with a larger number of counterparties, looking to take a larger (and more diverse) number of exposures.
} 
termediaries have engaged in some sort a grand conspiracy to make financial markets more complex. What I am suggesting, however, is that re-conceptualizing financial innovation as a process of change influenced by the incentives of innovators-who have the most to gain and possess a comparative informational advantage-can enhance our understanding of the complex and rapidly evolving dynamics within modern financial markets. What is more, re-conceptualizing financial innovation in this light serves to illuminate the regulatory challenges stemming from the interaction of complexity and innovation. We will turn our attention to these challenges in a moment. First, however, it is important to unpack the multifaceted relationship between complexity and financial innovation.

\section{The Relationship between Complexity and Financial Innovation: Three Case Studies}

As may already be apparent, complexity and financial innovation are mutually reinforcing dynamics. This symbiosis can be observed across at least four dimensions. First, as described above, complexity can be utilized by financial intermediaries for the purpose of preventing the commoditization of an innovation. Second, financial intermediaries that enjoy a higher tolerance for complexity relative to other market participants (and regulators) can exploit this advantage-i.e. extract rents-by offering "innovative" products and services which their clients may not fully understand. Third, newer and more innovative financial instruments invariably demand the incursion of high (initial) information costs on the part of both market participants and regulators. What is more, these instruments often (1) trade within less developed and more opaque markets and (2) generate unanticipated and undetected interconnections within and between financial markets and institutions, thereby exacerbating complexity. Finally, insofar as financial innovation is employed as a reflexive response to changes in the prevailing regulatory environment, both this innovation and the regulation that spawned it can be viewed as contributing to the complexity of modern financial markets.

\section{A. Complexity and Financial Innovation within OTC Derivatives Markets}

There exists no shortage of potential case studies illustrating various dimensions of the relationship between complexity and financial innovation. Three particularly compelling examples, however, are securitization, synthetic ETFs, and collateral swaps. It should come as no surprise that all three of these case studies are drawn from the world of OTC derivatives. ${ }^{161}$ OTC

${ }^{161}$ Nor that they are drawn from the vast, opaque, and intricately interconnected plumbing of the shadow banking system. 
derivatives markets have long been recognized at hotbeds of financial innovation. ${ }^{162}$ Perhaps more importantly, however, the dealer-intermediated microstructure that characterizes these markets has bestowed upon OTC derivatives dealers a distinct informational advantage-especially in terms of pricing and deal flow_vis-à-vis their clients, other market participants, and regulators.

The defining feature of this microstructure is the fact that dealers perform an explicit market-making role: structuring derivatives instruments and marketing them to clients on the basis that they are willing to take either side of the transaction. ${ }^{163}$ These dealers then typically look to eliminate the resulting exposures by seeking out and entering into offsetting transactions with other clients or, in many cases, other OTC derivatives dealers. ${ }^{164}$ Dealers are thus central-indeed, essential - to the operation of OTC derivatives markets: representing not only the primary source of innovation, but also of market access, information and liquidity. ${ }^{165}$ This reality is reflected in the concentration of trading activity within these markets. As of June 2010, for example, the fourteen largest OTC derivatives dealers (the so-called "G14") were responsible for approximately $82 \%$ of the global swaps market. ${ }^{166}$ This microstructure has historically deprived the marketplace of objective and transparent market-access and pricing mechanisms. To put it bluntly, OTC derivatives markets bear almost no resemblance to the perfect markets of conventional financial theory.

The information costs (and information failure) generated by this microstructure are compounded by, inter alia, the opacity of the LCFIs, hedge

${ }^{162}$ See, e.g., Darrell Duffie, Adn li \& Theo Lubke, Fed. Reserve Bank of N.Y., Policy Perspectives on OTC Derivatives Market Infrastructure 10 (2010), http:/ www.newyorkfed.org/research/staff_reports/sr424.pdf; Over-the-Counter Derivatives Markets Act of 2009, Hearing Before the H. Fin. Services Comm., 111th Cong. 5 (2009) (statement of René Stulz, Chair of Banking and Monetary Economics, The Ohio State University); Darrell Duffie \& Henry Hu, Competing for a Share of Global Derivatives Markets: Trends and Policy Choices for the United States 3 (Stanford University Rock Center for Corporate Governance. Working Paper No. 50, 2008), available at http://papers.ssrn.com/sol3/papers.cfm?abstract_id=1140869; Dan Awrey, Regulating Financial Innovation: A More Principles-Based Proposal?, 5 Brook. J. Corp. Fin. \& Com. L. 274 (2001).

163 This description is most apt in respect of swaps markets. The circumstance is somewhat more complicated in respect of many securitization markets, where dealers can also perform a role more closely resembling that of an underwriter in a traditional securities offering. Ultimately, the dealer's role will generally hinge on how bespoke the instrument is to the needs of a particular client or clients.

${ }^{164}$ See Deutsche Börse Group, The Global Derivatives Market: An Introiduction 17 (2008), available at http://math.nyu.edu/faculty/avellane/global_derivatives_market.pdf. Subject to applicable regulatory constraints, dealers can also engage in so-called "proprietary" trading for their own account.

${ }_{165}$ See Duffie \& Hu, supra note 162 , at 10.

${ }^{166}$ David Mengle, Concentration of OTC Derivatives Among Major Dealers, ISDA RESEARCH Notes, no. 4, 2010, at 1, available at http://www.isda.org/researchnotes/pdf/ConcentrationRN_4-10.pdf. Broken down by instrument, the G14 held $82 \%$ of the total outstanding notional amount of interest rate derivatives, $90 \%$ of CDS, and $86 \%$ of equity derivatives. Id. 
funds and many other counterparties that utilize OTC derivatives; ${ }^{167}$ the fragmentation that many OTC derivatives engender; ${ }^{168}$ and, in many cases, the sophisticated technical aspects of the instruments themselves. ${ }^{169}$ Furthermore, as amply illustrated by the GFC, the widespread use of OTC derivatives strengthens and expands the intricate web of interconnections within and between financial markets and institutions. Collectively, these attributes epitomize the complexity of modern financial markets. They also render securitization, synthetic ETFs and collateral swaps uniquely illuminating case studies in terms of both the relationship between complexity and financial innovation and, ultimately, the regulatory challenges posed by the interaction of these powerful market dynamics.

\section{B. Three Case Studies in Complexity and Financial Innovation}

\section{Securitization $^{170}$}

The case study that has to this point garnered the most scholarly attention is undoubtedly securitization. ${ }^{171}$ As described in Part II, securitization is a process whereby the cash flows associated with non-liquid assets are pooled together, restructured and sold as securities. Most structured finance vehicles are, in effect, a form of credit derivative. ${ }^{172}$ The first ABS was issued by the U.S. Government National Mortgage Association (Ginnie Mae) in 1970. ${ }^{173}$ This nascent ABS market initially revolved around the issuance of residential MBS by U.S. government sponsored enterprises (GSEs) such as Ginnie Mae, the Federal National Mortgage Association (Fannie Mae),

${ }^{167}$ See supra pp. 19-20. Indeed, the fact that the identity of counterparties to OTC derivatives matters cuts against the grain of conventional financial theory.

${ }^{168}$ See supra pp. 24-25.

${ }^{169}$ It is certainly the case that many OTC derivatives are (at least from an economic perspective) relatively straightforward to understand and use. It would take a small upfront investment to familiarize oneself with, for example, the basic structure and potential uses of a single currency interest rate of foreign exchange swap. At the same time however, the derivatives universe is populated by a diverse array of far from complex instruments. For a comprehensive description of the technical aspects of many of these instruments, see SATYAJTT DAS, THE Swaps and Financial Derivatives Library: Products, Pricing, Applications and Risk Managicmint (3d ed. 2005); Richard Ft.aviti, Swar's and Othis Dirivativtss (2d ed. 2009).

${ }^{170}$ Some might object, perhaps justifiably, to the assertion that securitization vehicles constitute OTC derivatives. Ultimately, however, while there are important economic (and legal) distinctions between securitization vehicles and other species of derivatives (e.g., swaps, options, etc.), they do ultimately fall within the generic-if somewhat overbroad-definition of a derivative as a financial contract the value or expected performance of which is linked to another, underlying, asset or assets.

${ }^{171}$ See e.g., Schwarcz, supra note 23; Gorton, supra note 30; Bartlett, supra note 31; Jackson, supra note 69; Gubler, supra note 84; and Judge, supra note 91.

${ }^{172}$ Essentially because the obligations of the issuers of these securities to make periodic payments to the holders are contingent upon the (non-)performance of the underlying assets (as measured by their ability to generate the expected cash flows).

${ }^{173}$ Shelagh Heffernan, Modern Banking 46 (2005). 
and the Federal Home Loan Mortgage Corporation (Freddie Mac). ${ }^{174} \mathrm{Be}-$ tween 1970 and 2010, annual issuances within this so-called "agency" MBS market grew from approximately \$USD452 million to over \$USD1.9 trillion. ${ }^{175}$ As of June 30, 2011, the outstanding amount of U.S. mortgage-related securities stood at approximately \$USD7 trillion. ${ }^{176}$

Observing this success, private sector financial institutions-primarily large commercial and investment banks-began structuring and distributing "private label" ABS in the mid-1980s. ${ }^{177}$ Notably, the timing of this move roughly corresponded with the completion of the 1988 Basel Capital Accord (Basel I). These financial institutions employed the structures developed by the GSEs in connection with residential mortgages and quickly adapted them to securitize cash flows derived from a far broader range of underlying assets including, inter alia: commercial mortgages; home equity and student loans; automobile, aircraft and equipment leases; credit card receivables; corporate debt; swaps; and even other securitizations. ${ }^{178}$ Between 1985 and 2011, the outstanding amount of non-mortgage-related ABS issued in the U.S. and Europe grew over $1800 \%$-from an estimated SUSD1.2 billion to over \$USD2.2 trillion. ${ }^{179}$

The emergence and precipitous growth of both agency and private label securitization markets - to say nothing of the markets for CDOs and CDOsquared-are attributable to a complex bundle of supply-side, demand-side, and other incentives. The agency ABS market, for example, grew at least in part out of a desire on the part of the U.S. federal government to expand home ownership, essentially as a means of ameliorating rising economic inequality. ${ }^{180}$ Investors, meanwhile, flocked to ABS, CDOs, and other securitizations in search of both (1) higher yields ${ }^{181}$ and (2) diversified exposure to, inter alia, the U.S. residential and commercial property sectors. ${ }^{182}$ Ultimately, however, much of this growth is attributable to the supply-side in-

\footnotetext{
${ }^{174}$ Prohibited by law from originating mortgages, the GSEs would acquire mortgages from private lenders, securitize them, and then guarantee the income streams generated by the resulting MBS. Id. at 47.

${ }^{175}$ U.S. Mortgage-Related Securities Issuance, SEC. Indus. AND FIN. MKT Assoc (SIFMA), http:/www.sifma.org/uploadedfiles/research/statistics/statisticsfiles/sf-us-mortgagerelated-issuance-sifma.xls (last visited June 13, 2011).

${ }^{176}$ U.S. Mortgage-Related Securities Outstanding, Sזc. Intuss. ANT Fin. Mkt Assoc (SIFMA), http://www.sifma.org/uploadedfiles/research/statistics/statisticsfiles/sf-us-mortgage-related-outstanding-sifma.xls (last visited Aug. 1, 2011).

${ }^{177}$ SIFMA, supra note 175; HefFERNAN, supra note 173 , at 47.

${ }^{178}$ See U.S. Asset-Backed Securities Outstanding, Src. Indus. And Fin. Mkt Assoc (SIFMA), http:/www.sifma.org/uploadedfiles/research/statistics/statisticsfiles/sf-us-abssifma.xls (last visited July 5, 2011).

${ }^{179}$ Id.; Europe Structured Finance Outstanding, SEC. Indus. AND FIN. MKT Assoc (SIFMA), http://www.sifma.org/uploadedfiles/research/statistics/statisticsfiles/sf-europe-outstanding-addendum-data-tables-eur-afme-sifma.xls (last visited May 25, 2011).

${ }^{180}$ See Raghuram Rajan, Fauit Linis: How Hidjin Fracturis Stil. Thriatian thi:

World ECONOMY 34-45 (2010); Fin. Crisis InQuiry Comm'n, supra note 6, at 38-42.

${ }^{181}$ See Turner, supra note 129.

182 See Fin. Crisis Inquiry Comm'n, supra note 6, at 43.
} 
centives of the commercial and investment banks, which structured and sold these securities. As a preliminary matter, financial institutions sponsoring securitized offerings earned sizable fees in connection with these transactions. What is more, securitization enabled originators to shift the market, liquidity, interest rate, and other risks associated with the underlying assets off their balance sheets. Most importantly, however, securitization enabled banks to secure relief from capital adequacy requirements, ${ }^{183}$ thus freeing up capital for reinvestment. ${ }^{184}$ Viewed in this light, the supply-side incentives come front and centre: the more assets a bank could repackage and sell via securitization, the more capital it could deploy toward new investments, and the more assets it would have to fuel the securitization machine. Introduce CDOs and CDO-squared into this mix - and thus the ability to make new assets out of thin air - and it is little wonder that securitization markets witnessed such exponential growth in the decades leading up to the GFC.

The complexity generated by the constant stream of new innovation within ABS, CDO, and other securitization markets is well documented. As both Gorton and Coval et. al. observe, many of the most (ostensibly) sophisticated institutional investors failed to fully grasp the complex technical aspects of both mortgage-backed ABS and the more complex CDOs into which they were repackaged. ${ }^{185}$ Along the same vein, the structure of many of these instruments undermined the ability of both underwriters and investors to effectively screen for and monitor asset and creditor quality. ${ }^{186}$ These informational problems became more acute with each successive fragmentation node. ${ }^{187}$ Ultimately, these factors combined to obscure from view the enormous risks building within this market.

\section{Synthetic ETFs}

A second (and considerably less notorious) case study illustrating the relationship between complexity and financial innovation is the burgeoning market for synthetic ETFs. ETFs are exchange-traded investment funds de-

${ }^{183}$ While a detailed examination of capital adequacy requirements is well beyond the scope of this paper, these requirements-and specifically those articulated under Basel I, II, and III-prescribe, inter alia, that banks and certain other classes of financial institution maintain a specified ratio of capital to risk-weighted assets. Insofar as many securitization vehicles attract a lower risk weighting than the underlying assets under these requirements, financial institutions will ceteris paribus be required to hold a lower amount of capital and, accordingly, will be incentivized to repackage and sell these assets via securitization.

${ }^{184}$ See Viral Acharya, Phillipp Schnabel \& Gustavo Suarez, Securitization Without Risk Transfer, FED. RESERve BANK of Richmond (Aug. 2011), http://www.richmondfed.org/conferences_and_events/research/2009/pdf/suarez_paper.pdf; Fin. CRISIs InquiRy Comm'N, PRT:LiminARY St'AfF RePORT: OverviEW ON Derivatives 6 (June 29, 2010), http://fcicstatic.law.stanford.edu/cdn_media/fcic-reports/2010-0630-psr-derivative-overview.pdf; Alan Greenspan, The Role of Capital in Optimal Banking Supervision and Regulation, FED. REStrvit Bank of N.Y. Econ. Poi.'y Rivv. 163, 165-66 (1998).

${ }_{185}$ See Gorton, supra note 30, at 20-34; Coval et. al., supra note 62.

${ }^{186}$ See Gorton, supra note 30, at 45, 59; Jackson supra note 69.

${ }^{187}$ See Judge, supra note 91 , at 3. 
signed to replicate the value of a portfolio of assets (e.g. the FTSE, S\&P 500 , or MSCI Emerging Markets Index). ${ }^{188}$ ETFs are generally regarded as low cost and liquid vehicles for investors seeking portfolio diversification. ${ }^{189}$ Their economic rationale is thus very much grounded in MPT. Introduced in the early 1990s, plain vanilla ETFs physically replicate the reference portfolio by purchasing the underlying assets. ${ }^{190}$ Synthetic ETFs, in contrast, are a more recent innovation designed to replicate the reference portfolio through the use of OTC derivatives. ${ }^{191}$

While there exist a number of ways to structure a synthetic ETF, perhaps the most common technique involves the sponsor of the fund entering into a total return swap ${ }^{192}$ with a financial intermediary. ${ }^{193}$ There are two components — or "legs" — of this swap. In the first leg, the ETF sponsor contracts with the financial intermediary to receive the total return on the reference portfolio in exchange for cash equal to the notional amount of the swap. ${ }^{194}$ In return, the financial intermediary transfers a portfolio of collateral to the ETF sponsor. Importantly, the collateral assets are often unrelated to those that the synthetic ETF has been designed to replicate. ${ }^{195}$ The second

${ }^{188}$ The investment firm BlackRock estimates that there are now in excess of 2,700 ETFs worldwide, replicating various portfolios of public equity and debt securities, across virtually every conceivable investment style, country and region. See Exchange-traded Funds: Too Much of a Good Thing, Economisr (June 25, 2011), available at http:/www.economist.com/ node/ 18864254 .

${ }^{189}$ See In't' Monetary Fund, Global Financial Stabllity Repori-Durable FinanCial Stability: Gisting Thist: rirom Hiris 68 (Apr. 2011), available at http://www.imf.org/ external/pubs/ft/gfsr/2011/01/index.htm; Fin. Stability Bd., Potenitial Financial Stability Issutes Aristag From Rncint Trindss in Exchangir-Tration Funds (ETFs) 1 (Apr. 12, 2011), available at http://www.financialstabilityboard.org/publications/r_110412b.pdf; B $\wedge \mathrm{NK}$

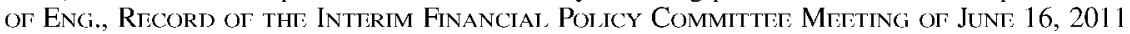
8 (June 24, 2011), http://www.bankofengland.co.uk/publications/Documents/records/fpc/pdf/ 2011/record 1 106.pdf.

${ }^{190}$ See Srichander Ramaswamy, Market Structures and Systemic Risks of ExchangeTraded Funds 1, (Bank for Int'l Settlements, Working Paper No. 343, 2011), available at http:// www.bis.org/publ/work343.pdf.

${ }^{191}$ See id. at 8; Fin STABח ITY BD., supra note 189, at 2.

${ }^{192}$ A prototypical total return swap (or TRS) involves swapping cash flows calculated with reference to a floating rate of interest for those derived from the total return (i.e., all capital gains and interest and dividend income) on a given asset or portfolio of assets. See Ramaswamy, supra note 190 , at 5.

${ }^{193}$ This structure is commonly referred to as the "unfunded swap structure." Id. This is in contrast to the "funded swap structure," which, in a nutshell, involves the ETF sponsor buying a structured note secured by a collateral pledge from a financial intermediary. Notably, in the funded swap structure, the financial intermediary posts eligible collateral into a ring-fenced custodial account. Accordingly, unlike the unfunded swap structure, the ETF sponsor is not the beneficial owner of the collateral assets. See id. at 6 for further details.

${ }^{194}$ See id. This has the benefit of transferring the tracking risk in the reference portfolio to the swap counterparty.

${ }_{195}$ See id. at 5; Too Much of a Good Thing, supra note 188. For ETFs domiciled in the E.U., for example, the Undertakings for Collective Investments in Transferrable Securities (UCITS) Directive $88 / 220 / \mathrm{EEC}$ (as amended) only prescribes that the collateral assets be selected from among certain prescribed classes of equity or debt securities. See Coucil Directive 88/220, arts. 22-23, 1988 O.J. (L100) 31, 32 (ED); Fin. STABility BD., supra note 189, at 4. 
leg of the swap then involves the transfer of the total return on the collateral package back to the financial intermediary. ${ }^{196}$

Synthetic ETFs have thus far proven especially popular in Europe and Asia. ${ }^{197}$ The growing demand for these derivatives has been stoked by institutional investors in search of higher returns in less liquid fixed income and emerging markets where physical replication of the reference portfolio would almost certainly prove prohibitively expensive. ${ }^{198}$ At least some of the impetus for the development of synthetic ETFs, however, stems from the desire on the part of the financial intermediaries acting as swap counterparties to remove less liquid collateral from their balance sheets-ultimately with a view to enhancing their liquidity profile, lowering securities warehousing costs, and once again, obtaining relief from regulatory capital requirements. ${ }^{199}$ In the extreme-and in particular where the financial intermediary is affiliated with the fund sponsor-synthetic ETFs can thus be utilized as a "dumping ground" 200 for lower quality assets. ${ }^{201}$ This in turn serves to highlight the fact that these instruments expose investors to both (1) counterparty credit risk in connection with the swap itself and (2) market and liquidity risk in connection with the swap collateral. ${ }^{202}$ Accordingly, while synthetic ETFs are themselves exchange-traded (and thus highly regulated ${ }^{203}$ ) instruments, their complexity and risk profile more closely resemble the OTC derivatives that reside at the core of this increasingly popular investment fund structure.

The complexity associated with synthetic ETFs stems primarily from the opacity of the underlying swaps and, more specifically, their collateral packages. This opacity is illustrated by a recent exercise conducted by the BIS involving a widely traded synthetic ETF replicating the MSCI Emerging Markets Index. ${ }^{204}$ With the assistance of the fund sponsor, the BIS was able

196 See Ramaswamy, supra note 190 , at 5.

${ }^{197}$ See Fin. SIABllity BD., supra note 189 , at 3 . Synthetic ETFs are less popular in the U.S. owing to regulatory constraints imposed under the Investment Company Act of 1940, 15 U.S.C. \$ 80a (2012); see InT'L Monetary Fund, supra note 189, at 68. Notably, in March 2010 the SEC announced that it was conducting a review of the use of derivatives by ETFs. See Press Release, U.S. Sec. and Exch. Comm'n, SEC Staff Evaluating the Use of Derivatives by Funds 2010-45 (Mar. 2010), http:/www.sec.gov/news/press/2010/2010-45.htm.

${ }^{198}$ See Too Much of a Good Thing, supra note 188; Ramaswamy, supra note 190, at 1. These increased costs are attributable to, inter alia, the wider bid-ask spreads typically encountered within these markets. See Ramaswamy, supra note 190, at 4.

${ }^{199}$ See Ramaswamy, supra note 190, at 1, 8-10; FIN. STABII ITY BD., supra note 189, at 2; BANK OF ENG., supra note 189 , at 8 . In effect, synthetic swaps can thus be utilized to perform the same economic function (i.e., liquidity transformation) as collateral swaps.

${ }^{200}$ Too Much of a Good Thing, supra note 188 .

${ }^{201}$ See INT'1. MONITARY TUND, supra note 189 , at 71-72.

${ }^{202}$ See id.; Ramaswamy, supra note 190 , at 8-9. What is more, these risks are likely to be exacerbated during periods of market turmoil.

${ }^{203}$ As previously mentioned, these instruments are subject to the Investment Company Act in the U.S. and the UCITS Directive in the E.U., along with the rules of the exchange on which they trade.

${ }^{204}$ See Ramaswamy, supra note 190, at 9-10. This fund utilizes the "funded" swap structure. 
to determine that the collateral package for this fund contained over 1000 securities, consisting largely of Japanese equities and unrated U.S. corporate bonds. ${ }^{205}$ In the end, however, the BIS found that a more detailed breakdown of the assets in the collateral package was "not readily available"206 and that obtaining this information "would be a cumbersome process." 207 It is also worth noting that the geographic dispersion of the assets within the collateral package bears little relation to the emerging market portfolio the fund is designed to replicate. The BIS exercise thus reinforces the concern that investors in synthetic ETFs may be operating with less than perfect information respecting the risks to which they are ultimately exposed.

\section{Collateral swaps s $^{208}$}

Our final case study is the emerging market for so-called "collateral swaps." A collateral swap is essentially a form of secured lending whereby one counterparty transfers relatively liquid assets to another in exchange for a pledge of less liquid collateral ${ }^{209}$ In a typical collateral swap, a bank holding a portfolio of $\mathrm{ABS}$ or other securitizations will transfer these assets to a pension fund or insurance company, which, in exchange for a periodic fee, will deliver a portfolio of more liquid collateral such as high-grade government or corporate bonds. ${ }^{210}$ The pension fund or insurer thereby receives a higher yield on its (ostensibly) safe investments, while the bank obtains access to a portfolio of liquid assets which it can then re-pledge to obtain funding from central banks and other sources which, in the wake of the GFC, have been less willing to accept ABS and other securitizations as eligible collateral. ${ }^{211}$ The development of collateral swaps is thus, in effect, an innovative response to both the post-crisis funding constraints on banks and

${ }^{205} I d$.

${ }^{206} \mathrm{Id}$.

${ }^{207} I d$.

${ }^{208}$ As with securitization, there is a very legitimate argument that, despite their name, collateral swaps should not be categorized as OTC derivatives. Indeed, insofar as these instruments are structured as long-dated repo contracts, they bear little similarity with more traditional swaps (i.e., a series of forward agreements).

${ }^{209}$ For this reason, these transactions are often referred to within collateral management circles as "liquidity transfers." In effect, collateral swaps are economically quite similar to a long-dated repo arrangement.

${ }^{210}$ See Jennifer Hughes, Concern Mounts Over Rise of Collateral Swaps, FTN. TIMTs (June 30, 2011), http://www.ft.com/int1/cms/s/0/e4109c9c-a31f-11e0-a9a4-00144feabdc0.html\#axzz lqlGMk8Zz; Izabella Kaminska, The Privatization of Liquidity Ops, FIN. TIMIs (December 17 , 2010), http://ftalphaville.ft.com/blog/2010/12/17/439851/the-privatisation-of-liquidity-ops/; Izabella Kaminska, It's Stock Lending Jim, But Not As You Know It, Fin. Times (Oct. 28, 2010), http:/ftalphaville.ft.com/blog/2010/10/28/386786/its-stock-lending-jim-but-not-as-youknow-it; Aaron Wollner, Funding Needs Drive Banks to "Borrow" Liquidity from Insurers and Pensions Funds, LifE \& PENsion Risk (Oct. 28, 2010), http://www.risk.net/life-and-pensionrisk/news/1814219/funding-drive-banks-borrow-liquidity-insurers-pension-funds.

211 See Hughes, supra note 210. 
the need to satisfy new liquidity requirements soon to be imposed under Basel III. ${ }^{212}$

Collateral swaps contribute to the complexity of modern financial markets in at least three ways. First, the collateral swap market is extremely opaque. Nobody knows with any certainty, for example, how big this market is, who the major players are, or the size of the aggregate exposures. As a result, it is exceedingly difficult to ascertain the nature and extent of the attendant risks. ${ }^{213}$ Second, given the identity of the counterparties, collateral swaps seem destined to strengthen the interconnections between banking markets, on the one hand, and insurance and pension funds, on the other. Finally, as described above, collateral swaps are a reflexive response to changes in the post-crisis market and regulatory environment.

Taken together, securitization, synthetic ETFs, and collateral swaps exemplify both the complexity of modern financial markets and the nature and pace of financial innovation. The salient question thus becomes: what are the regulatory challenges flowing from the interaction of these ubiquitous forces?

\section{Complexity and Financial Innovation: The Regulatory Challenges}

As amply illustrated by our three case studies, complexity and financial innovation together generate a host of regulatory challenges. Sophisticated new instruments, derived from esoteric financial theory, structured in ways that obscure the attendant risks, and traded in opaque dealer-intermediated markets by opaque financial institutions raise clear investor-protection issues. Paramount among these is the potential for both (1) uninformed (suboptimal) contracting, ${ }^{214}$ and (2) fraud, misconduct, and other opportunistic behavior on the party of financial intermediaries. The potential for suboptimal contracting in turn raises the prospect of both overinvestment and excess leverage leading, ultimately, to the build-up of systemic risk.

Simultaneously, opacity and the pace of innovation also render it more difficult for regulators to effectively police financial markets and-in conjunction with interconnectedness and fragmentation-to locate and monitor potential risks. Meanwhile, the vast array of intricate, evolving and often undetected interconnections within and between markets and institutionsthemselves often the byproducts of financial innovation-foment systemic

${ }^{212}$ See id. In effect, the counterparties to collateral swaps are arbitraging differences in the capital adequacy regimes applicable to banks, on the one hand, and pension funds and insurance companies, on the other.

${ }^{213}$ See BANK or ENG., supra note 189 , at 8.

${ }^{214}$ As Milton Friedman observed, optimal contracting necessitates that the actions of parties to a transaction are both voluntary and informed. Mit ton FriIidman, Capitailsm AND FREEDOM 13 (1962). Accordingly, where counterparties face high information costs, asymmetries of information and the resulting agency costs problems, there is reason to question the private (and social) optimality of the contracts into which they enter. 
fragility and manifest the potential to become channels for the transmission of contagion during periods of market distress. ${ }^{215}$ Reflexivity contributes still further to this fragility insofar as its self-reinforcing feedback effects drive the formation of asset bubbles. 216

Financial innovation itself represents yet another source of systemic vulnerability. Newer, less liquid, and highly concentrated markets frequently lack the legal, operational, or risk-management infrastructure necessary to withstand financial shocks. ${ }^{217}$ Compounding matters, the appropriability of financial innovation dilutes the incentives of market participants to invest in the development of such infrastructure. ${ }^{218}$ In the end, financial regulators face the decidedly daunting prospect of mounting effective responses to these (and other) challenges as, all the while, the forces of regulatory arbitrage-often in the guise of financial innovation-shift the ground beneath their feet.

Lurking in the background is one final regulatory challenge: welfare indeterminacy. Regulators cannot directly observe the preferences of their constituents, nor do they have any practical means of aggregating these preferences into a social welfare function. ${ }^{219}$ Simultaneously, they possess imperfect knowledge of (exogenous) future events and the (endogenous) welfare consequences of their policy choices.220 These blind spots limit the ability of regulators to evaluate the net welfare effects of, inter alia, (1)

${ }^{215}$ Essentially, these interconnections exacerbate informational problems during periods of market distress as financial institutions seek to determine the sources and scope of their potential exposures. Where the informational costs are too great, the resulting uncertainty can lead to panic and the mass withdrawal of liquidity from the financial system. See, e.g., Schwarcz, supra note 23; Gorton, supra note 30; Caballero \& Simsek, supra note 84. What is more, these interconnections may result in the transmission of financial shocks faster than regulators are able to address them. See Schwarcz, supra note 23, at 215 (citing W. Brian Arthur, Complexity and the Economy, SCIINCE (Apr. 2, 1999), http://www.sciencemag.org/ content/284/5411/107.full).

${ }^{216}$ See Soros, supra note 109 , at 23.

${ }^{217}$ See Gubler, supra note 84 , at 15.

${ }^{218}$ See Hu, supra note 29 , at 1482 . Indeed, such under-investment is part of a broader issue stemming from the fact that financial stability is, in effect, a public good.

${ }^{219}$ Indeed, many critics of welfare economics have gone so far as to suggest that the concept of social welfare is both logically incoherent and inherently contested. For an overview of these objections, see Timothy Besley, Principled Agents? The Political EconOMy of Good Government 21-23 (2006). Perhaps most notably, the assumption that the aggregation of individual utilities or preferences into a social welfare function is in fact possible has been challenged by Kenneth Arrow. See generally Kenneth Arrow, A Difficulty in the Concept of Social Welfare, 58 J. PoL. Econ. 328 (1950). Arrow argued that the task of aggregating individual preferences is "plagued by the difficulties of interpersonal comparison." Id. at 329. Under certain specified conditions, Arrow illustrated that a rational paradox could result from the aggregation of the preferences of as few as two individuals faced with as few as three potential states, thus precluding the construction of a social welfare function. For a discussion of the unrealistic nature of many of the assumptions underpinning Arrow's analysis, see Awrey, supra note 13, at n.52.

${ }^{220}$ Indeed, we do not even know with certainty which future events are exogenous and which are endogenous. Furthermore, even if we could determine the net welfare effects of a given policy choice at a particular moment in time, there is no guarantee that it would be representative of the net effects at any other moment. 
existing financial institutions, instruments and markets; $(2)$ existing regulation; (3) financial innovation; or (4) contemplated regulatory intervention. It is impossible to know with any real certainty, for example, whether the net social costs of taxpayer-funded bailouts for the financial institutions at the epicenter of the GFC exceed those which would have resulted from the economic turmoil that these bailouts likely averted; 221 whether the systemic benefits flowing from the implementation of the Basel III capital adequacy framework will outweigh any attendant costs in terms of lost economic growth, 222 or whether the benefits of OTC derivatives stemming from more complete markets, enhanced price discovery, and improved market liquidity exceed the costs arising from inefficient contracting, opportunistic behavior and potential systemic risks. What is certain, however, is that this welfare indeterminacy represents a significant regulatory challenge.

The common theme running through this inventory of regulatory challenges is the existence of pervasive, acute, and often deeply entrenched asymmetries of information and expertise within modern financial markets. These twin asymmetries-exacerbated, if not always caused, by complexity and financial innovation-can be observed both within the marketplace itself and, importantly, between market participants and regulators. These asymmetries have combined to make the entire financial system increasingly reliant on a relatively small oligopoly of intermediaries which serve as the repositories and purveyors of this information and expertise. As made all too clear by the economic turmoil unleashed by the GFC, the nature and extent of this reliance has generated what can fairly be described as the mother of all agency cost problems.

\section{OtC Derivatives Regulation in the Wake of the GFC: A Brave New World}

Prior to the GFC, the approach adopted toward OTC derivatives regulation in jurisdictions such as the U.S. and U.K.- which account for the vast

${ }^{221}$ Although this has not stopped scholars from attempting to quantify these costs. See Pietro Veronesi \& Luigi Zingales, Paulson's Gift (Chicago Booth Sch. of Bus., Research Paper No. 09-42, 2009), available at http://papers.ssrn.com/sol3/papers.cfm?abstract_id=1498548.

${ }^{222}$ Although, once again, this has not stopped various observers from attempting to quantify these costs. See e.g., Patrick Slovik \& Boris Cournède, Macroeconomic Impact of Basel III (OECD Econ. Dep't, Working Paper No. 844, 2011), available at http://www.oecdilibrary.org/economics/macroeconomic-impact-of-basel-iii_5kghwnhkkjs8-en; Douglas Elliott, Basel III, the Banks, and the Economy, The Brookings Insr. (July 23, 2010), http:// www.brookings.edu/ /media/Files/rc/papers/2010/0726_basel_elliott/0726_basel_elliott.pdf; The Inst. of Ini's Fin., Interim Cumulative EFfect Report (June 2010), available at http:// www.ebf-fbe.eu/uploads/10-Interim\%20NCI_June2010_Web.pdf; Douglas Elliott, Quantifying the Effects on Lending of Increased Capital Requirements, ThE BRoOKIngs Inst. (Sept. 21, 2009), http://www.brookings.edu/ /media/Files/rc/papers/2009/0924_capital_elliott/ 0924_capital_elliott.pdf. 
majority of global trading activity ${ }^{223}$ — can perhaps best be described as "non-interventionist." 224 Swaps markets effectively (if not at all times legally) fell outside the perimeter of securities and futures regulation in both jurisdictions. ${ }^{225}$ ABS, CDOs, and other securitizations, meanwhile, were frequently offered under exemptions from the prospectus, registration, and other requirements imposed under applicable securities laws. ${ }^{226}$ This noninterventionist approach was shaped by the prevailing free market ideology which viewed market participants as invariably best positioned to address the risks arising in connection with OTC derivatives. ${ }^{227}$ It was also influenced by mounting competitive pressures within the increasingly global

${ }^{223}$ As of April 2010, for example, these two jurisdictions accounted for roughly $70 \%$ of global turnover in OTC interest rate derivatives and $55 \%$ of the global turnover in OTC foreign

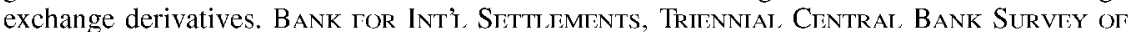

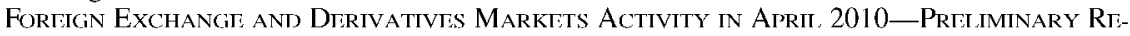
sutcs 5-6 (Sept. 2010), available at http://www.bis.org/publ/rpfx 10.pdf. Other jurisdictions with a meaningful share of global turnover in these instruments include Japan $(6 \%$ of OTC foreign exchange derivatives and $3 \%$ of OTC interest rate derivatives), Singapore (5\% and $3 \%)$ and Switzerland (5\% and 3\%). Id. While reliable comparable data for equity, credit and commodity-linked derivatives is more difficult to come by, the available data suggests a similar (if not greater) degree of geographic concentration within these market segments. See Duffie \& $\mathrm{Hu}$, supra note 162 , at $12-16$.

${ }^{224}$ A handful of observers have suggested that, despite appearances, the U.S. Federal Reserve Board and other federal banking regulators actually played a robust oversight role in respect of OTC derivatives. See, e.g., Schuytir Hianderson, Hintisisson on Dirivativis (2d ed. 2010). Ultimately, however, these observers downplay (or altogether ignore) the myriad of ways in which these regulators systematically relaxed the regulatory rules surrounding these instruments in the decades leading up to the GFC. For a survey of these actions, see Awrey, supra note 103; Saule Omarova, The Quiet Metamorphosis: How Derivatives Changed the "Business of Banking," 63 U. Mıм L. Rev. 1041 (2009); Saule Omarova, From GrammLeach-Bliley to Dodd-Frank: The Unfulfilled Promise of Section 23A of the Federal Reserve Act, 89 N.C. L. Rrv. 1683 (2011). More fundamentally, these observers seemingly fail to appreciate the rather obvious point that U.S. banking regulators do not enjoy jurisdiction over global markets.

${ }^{225}$ See Awrey, supra note 103, for a detailed description of the pre-crisis regulatory treatment of swaps in both the U.S. and U.K.

${ }^{226}$ In the U.S., for example, exemptions could be obtained under sections 3(a)(2) and 4(2) of the Securities Act of 1933, 15 U.S.C. $\$ \$ 77 a-3(a)(2), 77 a-4(2)(2012)$, and sections 3(c)(1) and $3(\mathrm{c})(7)$ of the Investment Company Act of 1940,15 U.S.C. $\$ \$ 80 \mathrm{a}-3(\mathrm{c})(1), 80 \mathrm{a}-3(\mathrm{c})(7)$ (2012). Very briefly, Section 3(a)(2) of the Securities Act of 1933 provides an exemption for securities issued by federally regulated banks and savings and loan associations. \$77a-3(a)(2). Section 4(2) of the Securities Act of 1933 provides an exemption for transactions not involving a public offering of securities. $\$ 77 \mathrm{a}-4(2)$. Section 3(c)(1) of the Investment Company Act of 1940 provides an exemption where the beneficial holders of outstanding securities number less than 100 at any time. $\$ 80 \mathrm{a}-3(\mathrm{c})(1)$. Section 3(c)(7) of the Investment Company Act of 1940 , meanwhile, provides an exemption where the issuer does not make a public offering and the securities are owned by certain qualified purchasers (i.e. those meeting a prescribed income or asset test). $\$ 80 \mathrm{a}-3(\mathrm{c})(1)$. The SEC would subsequently expand the available exemptions through the promulgation of Rule 144A under the Securities Act of 1933 (adopted in 1990) and Rule 3a-7 under the Investment Company Act of 1940 (adopted in 1992).

${ }^{227}$ The influence of this ideology is most clearly visible in connection with the Congressional hearings leading up to the enactment of the Commodity Futures Modernization Act of 2000, Pub. L. No. 106-554, 114 Stat. 2763 (2000), which, inter alia, prohibited federal securities and futures regulators from regulating OTC derivatives markets. See Greenspan, The Regulation of OTC Derivatives, supra note 12. 
market for investment banking services. ${ }^{228}$ Ultimately, however, this approach effectively disregarded the risks and regulatory challenges generated by complexity and financial innovation. The \$USD700 trillion dollar question thus becomes: what lessons, if any, have policymakers taken away from the GFC?

The frenzied and destructive events of March-September 2008 spurred policymakers on both sides of the Atlantic to fundamentally reevaluate their approaches toward the regulation of OTC derivatives markets. ${ }^{22}$ This "rethink" was motivated by two principal observations. First, when the chips were down, the size, technological sophistication, opacity, interconnectedness, and fragmentation of OTC derivatives markets-in short, their complexity - meant that nobody knew with any certainty where or how big the counterparty credit (and thus systemic) risks were. Second, bilateral risk management-i.e. privately negotiated collateral and netting arrangements-had not effectively mitigated these risks. Manmohan Singh, for example, has estimated that as of 2008 bilateral swap markets were undercollateralized by as much as \$USD2 trillion. ${ }^{230}$ Perhaps most importantly, prevailing market practice dictated that intra-dealer exposures were often entirely uncollateralized. ${ }^{231}$

On March 4, 2009, the European Commission announced its commitment to implement reforms designed to increase transparency and reduce systemic risk within OTC derivatives markets. ${ }^{232}$ This commitment would eventually be met in the form of the E.U. Regulation on OTC Derivatives,

${ }^{228}$ See Duffie \& Hu, supra note 162, at 12-16; McKInsEY \& Co., supra note 96.

229 This shift began (modestly enough) in March 2008-in the immediate aftermath of the Bear Stearns bailout-when the CFTC and SEC entered into a mutual cooperation agreement with a view to enhancing coordination and facilitating the review of new derivatives instruments. See Press Release, Commodity Futures Trading Comm'n, CFTC, SEC Sign Agreement to Enhance Coordination, Facilitate Review of New Derivatives Products (Mar. 11, 2008), http://www.sec.gov/news/press/2008/2008-40.htm. Then, in November, the CFTC, SEC, and Federal Reserve Board entered into a memorandum of understanding to establish a framework for consultation and information sharing on regulatory issues related to central counterparties for CDS contracts. See History of the CFTC, U.S. Commontty Futures Trading Comm'n, www.cftc.gov/About/HistoryoftheCFTC/history_2000s.html (last visited Mar. 18, 2012). Shortly thereafter, the CFTC announced that the CME had certified a proposal to clear CDS through the CME's clearing facilities. See Press Release, Commodity Futures Trading Comm'n, CFTC Announces that CME Has Certified a Proposal to Clear Credit Default Swaps (Dec. 23, 2008), http://www.cftc.gov/PressRoom/PressReleases/pr5592-08.

${ }^{230}$ As measured by derivatives payables. Manmohan Singh, Collateral, Netting and Systemic Risk within OTC Derivatives Markets (Int'l Monetary Fund, Working Paper 10/99, 2010). See also Manmohan Singh and James Aitken, Counterparty Risk, Impact on Collateral Flows and Role for Central Counterparties (Int'l Monetary Fund, Working Paper 09/173, 2009); Miguel Segoviano Basurto and Manmohan Singh, Counterparty Risk in the Over-TheCounter Derivatives Market (Int'l Monetary Fund, Working Paper 08/258, 2008).

${ }^{231}$ See Singh, supra note 230 , at 7.

${ }^{232}$ See Driving European Recovery, Europenn Commission (Mar. 4, 2009), http://eurlex.europa.eu/LexUriServ/LexUriServ.do?uri=COM:2009:0114:FIN:EN:PDF. See also Ensuring Efficient, Safe and Sound Derivatives Markets: Future Policy Actions, EuropE $\triangle$ N CoMMISSION (October 20, 2009), http://eur-lex.europa.eu/LexUriServ/LexUriServ.do?uri=COM: 2009:0563:FIN:EN:PDF. 
Central Counterparties and Trade Repositories (or EMIR ${ }^{233}$ ), adopted on September 15, 2010.234 The U.S. Treasury Department, meanwhile, was also eager to signal its enthusiasm for a new approach: unveiling the draft Overthe-Counter Derivatives Markets Act in August 2009.235 These reforms would ultimately be enacted in July 2010 as part of the Dodd-Frank Wall Street Reform and Consumer Protection Act. ${ }^{236}$

\section{A. The U.S. Regulatory Response}

The Obama Administration has characterized the objectives of the new U.S. regime as to: (1) guard against the build-up of systemic risk; (2) promote transparency and efficiency; (3) thwart market manipulation, fraud, insider trading and other abuse; and (4) prevent inappropriate marketing to unsophisticated counterparties. ${ }^{237}$ Title VII of the Dodd-Frank Act employs four primary mechanisms in pursuit of these objectives. ${ }^{238}$ First, it confers upon the CFTC and SEC the authority to mandate that financial instruments falling within the definition of either a "swap" or "security-based swap" 239 be centrally cleared through CFTC-regulated derivatives clearing organizations or SEC-regulated securities clearing agencies (collectively, CCPs). ${ }^{240}$

\footnotetext{
${ }^{233}$ Which stands for the 'European Market Infrastructure Directive'.

${ }^{234}$ EMIR is not scheduled to come into full force and effect until December 31, 2012. The U.K. is obligated under E.U. law to implement EMIR. Eur. PArL. DOC. (COM 0484) (2010). ${ }^{235}$ See Press Release, U.S. Dep't of the Treasury, Administration's Regulatory Reform Agenda Reaches New Milestone: Final Piece of Legislative Language Delivered to Capitol Hill (Aug. 11, 2009), which includes the proposed text of the Over-the-Counter Derivatives Markets Act of 2009.

${ }^{236}$ While Title VII of the Dodd-Frank Act (governing OTC derivatives) technically came into force on July 16,2011, the effective date of the vast majority of the contemplated reforms has been delayed pending the completion of the requisite rulemaking process. Each of these reforms will take effect 60 days following the publication of the relevant final rule. See DoddFrank Wall Street Reform and Consumer Protection Act, Pub. L. No. 111-203, § 754, 24 Stat. $1376(2010)$.

${ }^{237}$ U.S. Dep't of the Treasury, supra note 235.

${ }^{238}$ Not including (1) the "push out" of (most) derivatives activities conducted by federally insured banks to separate non-bank affiliates, see Dodd-Frank Act $\$ 716$, or (2) the socalled "Volcker Rule" limiting the proprietary trading activities of bank holding companies. See id. $\$ 619$.

${ }^{239}$ Taken together, the definitions of swap and security-based swap encompass the vast majority of OTC derivatives instruments. See $i d$. $\$ \$ 721,761$. That said, the dividing line between swaps and security-based swaps is not altogether clear under the Dodd-Frank Act, especially with respect to swaps based on a portfolio of assets, such as those which often form the subject matter of structured finance transactions.

${ }^{240}$ See Dodd-Frank Act $\$ \$ 723,763$. Unless otherwise indicated, all subsequent references to "swap" shall, for the purposes of this description of the operative provisions of Title VII of the Dodd-Frank Act, be construed so as to include a "security-based swap." The process for determining whether a particular group, category, type, or class of swap be will subject to the central clearing and exchange-trading requirements can be initiated by either a CCP or the relevant regulator. See id. $\$ 723$ (a)(3). CCPs are required to submit to the CFTC or SEC, as applicable, "any group, category, type, or class of [security-based] swap" it intends to accept for clearing and provide notice of this submission to its members. Id. In reviewing a submission, the CFTC or SEC will determine whether the submission is consistent with the core principles of the relevant CCP. Id. The relevant regulator is also required to take into
} 
In very broad terms, CCPs interpose themselves between the counterparties to bilateral OTC transactions, effectively assuming the obligations of each party to the other. ${ }^{241}$ The principle advantage of centralized clearing and settlement through CCPs is the potential mitigation of both counterparty credit and systemic risk via the (1) multilateral netting of exposures, ${ }^{242}$ (2) collateralization of residual net exposures ${ }^{243}$ (3) enforcement of robust risk management standards, ${ }^{244}$ and (4) mutualization of losses resulting from the failure a clearing member. ${ }^{245}$ Simultaneously, of course, CCPs concentrate counterparty credit-and thus systemic - risk.

The Dodd-Frank Act contemplates an exemption from the clearing requirement if one of the counterparties (1) is not a "financial entity," (2) is using the instrument to "hedge or mitigate commercial risk," and (3) provides prescribed information to the relevant regulator respecting how it meets its financial obligations in connection with bilaterally cleared swaps. ${ }^{246}$ For the purposes of this commercial end-user exemption, a financial entity includes a swap dealer, ${ }^{247}$ major swap participant, ${ }^{248}$ and certain

account the following factors: (1) "the existence of significant outstanding notional exposures, trading liquidity, and adequate pricing data," (2) "the availability of a rule framework, capacity, operational expertise and resources, and credit support infrastructure to clear the contract on terms that are consistent with the material terms and trading conventions on which the contract is then traded," (3) "the effect on the mitigation of systemic risk, taking into account the size of the market for such contract and the resources of the CCP available to clear the contract," (4) "the effect on competition, including appropriate fees and charges applied to clearing," and (5) "the existence of reasonable legal certainty in the event of the insolvency of the relevant CCP or one or more of its clearing members with regard to the treatment of customer and swap counterparty positions, funds, and property." $I d$.

${ }^{241}$ See DuтTाז, Li \& LuBKr, supra note 162, at 5 . As Duffie and his co-authors explain, a "CCP stands between two original counterparties as the seller to the original buyer, and as the buyer to the original seller." Id. See also Guidance on the Application of the 2004 CPSSIOSCO Recommendations for Central Counterparties to OTC Derivatives $C C P s, \mathrm{~B} \triangle \mathrm{NK}$ FOR Int't Setti гmints \& Tichnicat Comm. or the Int't Org. or Src. Comm'n 1 (May 2010), http://www.bis.org/publ/cpss89.htm.

${ }^{242}$ Multilateral netting involves eliminating offsetting or redundant positions via, inter alia, the utilization of portfolio compression or so-called "tear up" procedures.

${ }^{243}$ Effectively creating a first loss position that serves as a capital buffer in the event of counterparty default.

${ }^{24}$ By prescribing rules respecting, for example, capital, initial and variation margin, collateral, position portability, segregation of client assets, and stress testing.

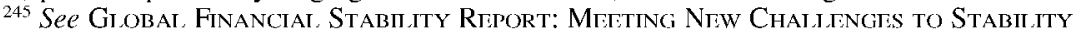
and Bulding a SAfer System, Int'l Monetary Fund 97 (Apr. 2010), available at http:// www.imf.org/external/pubs/ft/gfsr/2010/01/index.htm; Niw Dividopmints in Ci.taring and SetTlement Arrangements for OTC Derivatives, B $A$ nk for InT'L Set'llements (Comm. on Payment and Settlement Systems, Publ'n No. 77 2007), available at http:/www.bis.org/ publ/cpss $77 . \mathrm{htm}$.

${ }^{246}$ Dodd-Frank Wall Street Reform and Consumer Protection Act, Pub. L. No. 111-203, $\$ 723(\mathrm{a})(3), 24$ Stat. $1376(2010)$. The non-financial or hedging counterparty retains the option to require that the instrument be centrally cleared. $I d$.

${ }^{247}$ Section 721(a) of the Dodd-Frank Act and section 3(a)(71) of the Exchange Act define a swap dealer as: "any person who-(i) holds itself out as a dealer in [security-based] swaps; (ii) makes a market in [security-based] swaps; (iii) regularly enters into [security-based] swaps ... . ; or (iv) engages in any activity causing the person to be commonly known in the trade as a dealer or market maker in [security-based] swaps." Dodd-Frank Act \$ 721(a). This 
other identified classes of financial institution. ${ }^{249}$ In order to incentivize greater utilization of centrally-cleared derivatives, it is likely that the new regime will ultimately impose higher capital and margin requirements on both swap dealers and major swap participants in connection with bilaterally cleared swaps. 250

Second, the Dodd-Frank Act gives regulators the authority to require that any swap subject to the clearing requirement also trade on a regulated board of trade, exchange, or alternative swap execution facility. ${ }^{251}$ This execution requirement will not apply, however, where (1) no board of trade, exchange, or swap execution facility makes the swap available to trade or (2) one of the counterparties to the swap falls within the commercial end-user exemption to the clearing requirement. ${ }^{252}$ Where swaps are subject to this execution requirement, the expectation is that this will enhance price discovery, promote greater market transparency and curb opportunities for market abuse.

Third, the Dodd-Frank Act requires all swap dealers, ${ }^{253}$ major swap participants, ${ }^{254} \mathrm{CCPs},{ }^{255}$ swap execution facilities, ${ }^{256}$ and swap data repositories (SDRs) ${ }^{257}$ to register with the SEC, CFTC, or federal banking regulators.

definition does not include a person who enters into swaps for their own account (or in a fiduciary capacity), but does not do so as part of a regular business. Id.

${ }^{248}$ Section 721 (a) and 761(a) of the Dodd-Frank Act define a major swap participant as: "any person who is not a [security-based] swap dealer and-(i) maintains a substantial [net] position in swaps for any of the major swap categories as determined by the [relevant regulator], excluding (I) positions held for hedging or mitigating commercial risk .... (ii) whose outstanding swaps create substantial counterparty exposure that could have serious adverse effects on the financial stability of the United States banking system or financial markets." Dodd-Frank Act $\$ \$ 721$ (a), 761(a). The definition also includes a financial institution falling under the definition of financial entity as set out in the Dodd-Frank Act that is (1) highly leveraged, (2) not subject to capital requirements, and (3) maintains a substantial net position in outstanding swaps for any of the major swap categories as determined by the relevant regulator. Id. The definition of a "substantial position" is left to be defined by the relevant regulators. $I d$.

${ }^{249}$ See Dodd-Frank Act $\$ 723(\mathrm{a})(3)$.

${ }^{250}$ See U.S. Dep't of the Treasury, supra note 235 . Ultimately, however, the Dodd-Frank Act only mandates that the CFTC, SEC, and federal banking regulators, as applicable, set minimum capital and margin requirements. See Dodd-Frank Act $\$ \$ 731,764$. See also Margin Requirements for Uncleared Swaps for Swap Dealers and Major Swap Participants, 76 Fed. Reg. 23,732 (proposed Apr. 28, 2011) (to be codified at 17 C.F.R. pt. 23); Capital Requirements of Swap Dealers and Major Swap Participants, 76 Fed. Reg. 27,802 (proposed May 12, 2011) (to be codified at 17 C.F.R. pts. $1,23,140$ ).

${ }^{251}$ See Dodd-Frank Act $\$ \$ 723,763$. Section 721(a) defines a swap execution facility as "a trading system or platform in which multiple participants have the ability to execute or trade swaps by accepting bids and offers made by multiple participants in the facility or system." Dodd-Frank Act $\$ 721($ a).

${ }^{252}$ See id. $\$ 721$ (a).

${ }^{253}$ See id. $\$ \$ 731,764$.

${ }^{254}$ See id.

${ }^{255}$ See id. $\$ 725$

${ }^{256}$ See id. $\$ \$ 733,763$.

${ }^{257}$ See $i d . \$ \$ 728,763$. An SDR is a centralized registry that maintains a database of transaction records. SDRs may also manage trade life-cycle events and downstream trade processing services. See BANK fOR INT'L SETTLEments, supra note 241, at 1. 
Once registered, swap dealers and major swap participants are subject to, inter alia, capital, margin, reporting, recordkeeping, and business conduct requirements. ${ }^{258}$ CCPs registered with the CFTC, swap execution facilities and SDRs, meanwhile, are required to (1) comply with a set of "core principles" and other requirements and (2) design, implement, monitor, and enforce technical regulation in furtherance of these principles. ${ }^{259}$ While the Dodd-Frank Act does not articulate a similar set of core principles for CCPs registered with the SEC, it does mandate that the two agencies adopt consistent and comparable rules governing these registrants. ${ }^{260}$

Finally, the Dodd-Frank Act imposes extensive recordkeeping and reporting requirements on these new registrants. Swap counterparties are required to report all centrally and bilaterally cleared swaps to an SDR. ${ }^{261}$ SDRs, CCPs and swap execution facilities are then obligated to provide granular counterparty and transaction information to the relevant regulators. ${ }^{262}$ These regulators are, in turn, required to publically disseminate anonymized transaction and pricing data on a "real time" basis. ${ }^{263}$ This public reporting requirement is explicitly designed to enhance price discovery. ${ }^{264}$ More broadly, these requirements are designed to leverage the centralization of transaction data within SDRs, CCPs, swap execution facilities and other institutions with a view to generating greater market transparency and, as a consequence, enabling regulators to more effectively monitor the location, nature and extent of potential systemic risks. ${ }^{265}$

The Dodd-Frank Act carves up jurisdiction over bilateral OTC derivatives on the basis of a distinction between (1) contracts for the sale of a commodity for future delivery and swaps (subject to CFTC jurisdiction) and (2) security-based swaps (subject to SEC jurisdiction). ${ }^{266}$ Simultaneously, however, it mandates consistency and comparability between SEC and CFTC rules and regulations governing functionally or economically similar

${ }^{258}$ See Dodd-Frank Act $\$ \$ 731,764$. The capital and margin requirements will only apply in respect of bilaterally cleared swaps. The corresponding requirements for centrally cleared swaps will be set by the relevant CCP. See id. Section 737 also contemplates that the CFTC may set position limits (excluding bona fide hedges) for swaps that perform or affect a significant price discovery function with respect to registered entities. See id. $\$ 737$. See also Position Limits for Derivatives, 76 Fed. Reg. 4752 (proposed Jan. 26, 2011) (to be codified at 17 C.F.R. pts. $1,50,51$ ).

${ }^{259}$ Dodd-Frank Act $\$ \$ 725,728,733,763$.

${ }^{260}$ See id. $\$ 712(\mathrm{a})(7)$.

${ }^{261}$ See id. $\$ 727,729,766$. These provisions set out rules respecting which counterparty is required to report the swap. In the circumstance where no SDR will accept the swap, it must be reported directly to the relevant regulator. See id. $\$ \$ 729,766$. Notably, this reporting obligation also applies to swaps entered into prior to the enactment of the Dodd-Frank Act. See id.

${ }^{262}$ See id. $\$ \$ 725,728,733$.

${ }^{263}$ See id. $\$ 727$. For the purpose of these requirements, reporting on a "real time" basis refers to reporting within a time frame that is "technologically practicable." Id.

${ }^{264}$ See id.

265 See INT' Monitariny Fund, supra note 253 at $105-06$.

${ }^{266}$ See Dodd-Frank Act $\$ \$ 712,722,761-63$. 
products and registrants. ${ }^{267}$ To this end, the SEC and CFTC have been handed joint responsibility for fleshing out the innumerable technical details of the new regime. ${ }^{268}$ The two agencies are thus currently engaged in the monumental task of issuing proposed and final rules respecting, inter alia, the process by which regulators determine whether a swap will be subject to the clearing requirement; ${ }^{269}$ risk management and business conduct standards for CCPs, SDRs, swap dealers and major swap participants; ${ }^{270}$ margin and capital requirements for swap dealers and major swap participants, and ownership limitations and governance requirements for CCPs, designated contract markets, exchanges and swap execution facilities. ${ }^{271}$

The Dodd-Frank Act also seeks to enhance the regulation of ABS and other securitizations - including, importantly, those offered under exemptions from the prospectus and registration requirements under the Securities Act. ${ }^{272}$ First, it requires issuers of ABS and other securitizations to disclose

${ }^{267}$ See id. $\$ 712(\mathrm{a})$.

${ }^{268}$ See id. $\$ 712(\mathrm{~d})(1)$. Including the definitions of swap, security-based swap, swap dealer, security-based swap dealer, major swap participant, major security-based swap participant, and eligible contract participant. See id. The Obama Administration has requested and received a joint plan for harmonizing the regulation of OTC derivatives markets. See Joint Report of the SEC and the CFTC on Harmonization of Regulation, COMMODITY FuTURTs Trading Comm'n and Src. Ant Exch. Comm'n (Oct. 16, 2009), http:/www.cftc.gov/ucm/ groups/public/@otherif/documents/ifdocs/opacftc-secfinaljointreport 101.pdf.

${ }_{269}$ See Process for Review of Swaps for Mandatory Clearing, 76 Fed. Reg. 44,464 (July 26, 2011) (to be codified at 17 C.F.R. pts. 39, 140); Technical Amendments to Rule 19b-4 and Form 19b-4 Applicable to All Self-Regulatory Organizations, 75 Fed. Reg. 82,490 (proposed Dec. 15, 2010) (to be codified at 17 C.F.R. pts. 240, 249).

${ }^{270}$ See, e.g., Derivatives Clearing Organization General Provisions and Core Principles, 76 Fed. Reg. 69,334 (Nov. 8, 2011) (to be codified at 17 C.F.R. pts. 1, 21, 39, 140); Information Management Requirements for Derivatives Clearing Organizations, 75 Fed. Reg. 78,185 (proposed Dec. 15, 2010) (to be codified at 17 C.F.R. pts. 1, 21, 39); Business Conduct Standards for Swap Dealers and Major Swap Participants With Counterparties, 75 Fed. Reg. 80,638 (proposed Dec. 22, 2010) (to be codified at 17 C.F.R. pts. 23, 155); Swap Data Repositories, 75 Fed Reg. 80,898 (proposed Dec. 23, 2010) (to be codified at 17 C.F.R. pt. 49); Core Principles and Other Requirements for Swap Execution Facilities, 76 Fed. Reg. 1214 (proposed Jan. 7, 2011) (to be codified at 17 C.F.R. pt. 37). See also Security-Based Swap Data Repository Registration, Duties and Core Principles, 75 Fed. Reg. 77,306 (proposed Dec. 10, 2010) (to be codified at 17 C.F.R. pts. 240, 249); Registration and Regulation of Security-Based Swap Execution Facilities, 76 Fed. Reg. 10,948 (proposed Feb. 28, 2011 ) (to be codified at 17 C.F.R. 240, 242, 249); Business Conduct Standards for Security-Based Swap Dealers and Major Security-Based Swap Participants, 76 Fed. Reg. 42,396 (proposed July 18, 2011) (to be codified at 17 C.F.R. pt. 240).

${ }^{271}$ See e.g., Governance Requirements for Derivatives Clearing Organizations, Designated Contract Markets, and Swap Execution Facilities, 76 Fed. Reg. 722 (proposed Jan. 6, 201 1 ) (to be codified at 17 C.F.R. pts. 1, 37-40). See also Clearing Agency Standards for Operation and Governance, 76 Fed. Reg. 14,472 (proposed Mar. 16, 2011) (to be codified at 17 C.F.R. pt. 240); Ownership Limitations and Governance Requirements for Security-Based Swap Clearing Agencies, 76 Fed. Reg. 12,645 (Mar. 3, 2011) (to be codified at 17 C.F.R. 242).

${ }^{272}$ Section 943 of the Dodd-Frank Act introduced section 3(a)(77) of the Securities Exchange Act of 1934, which defines an "asset-backed security" as a fixed income or other security collateralized by any type of self-liquidating financial asset that allows the holder of the security to receive payments that depend primarily on the cash flows from that asset. See Dodd-Frank Wall Street Reform and Consumer Protection Act, Pub. L. No. 111-203, \$ 943, 24 Stat. 1376 (2010). Notably, the definition expressly includes both CDOs and CDO-squared. Id. 
information respecting the quality of the assets backing each tranche or class of security. ${ }^{273}$ Where necessary for investors to perform independent due diligence, issuers must also disclose more detailed asset or loan-level data. ${ }^{274}$ Second, it requires "securitizers" 275 to disclose fulfilled and unfulfilled repurchase requests across all trusts aggregated by the securitizer. ${ }^{276}$ Third, it compels credit rating agencies to include information in their rating reports respecting the representations, warranties, and enforcement mechanisms available to investors in connection with a securitization and, importantly, how these provisions differ from other offerings of similar securities. ${ }^{277} \mathrm{Fi}$ nally, it imposes risk retention requirements on securitizers: mandating that, in certain prescribed circumstances, ${ }^{278}$ they maintain at least $5 \%$ of the credit risk in connection with any assets they sell into a securitization. ${ }^{279},{ }^{280}$ As with the new regime governing swaps, the securitization provisions of the DoddFrank Act contemplate substantial post-enactment rulemaking. ${ }^{281}$

\section{B. The European Regulatory Response}

The scope and substantive requirements of the new European regime are broadly consistent with Title VII of the Dodd-Frank Act. ${ }^{282}$ EMIR mandates that all "eligible" 283 OTC derivatives between "financial counterpar-

${ }^{273}$ See Dodd-Frank Act $\$ 942$ (b). The Dodd-Frank Act then requires the SEC to adopt regulations prescribing the specific format and content of these disclosures. Id.

${ }^{274}$ See id.

${ }^{275}$ The Dodd-Frank Act defines a securitizer as (1) an issuer of an ABS or other securitization or (2) a person who organizes and initiates an ABS transaction by selling or transferring assets, either directly or indirectly, to the issuer. Dodd-Frank Act $\$ 941$ (b).

${ }^{276}$ See id. $\$ 943(2)$. The Dodd-Frank Act characterizes the objective of this provision as to make it easier for investors to identify asset originators with clear underwriting deficiencies. Id. This obligation only applies, however, where the transaction documentation contains a covenant to repurchase an asset. See Disclosure for Asset-Backed Securities Required By Section 943 of the Wall Street Reform and Consumer Protection Act, 76 Fed. Reg. 4489 (Jan. 26, 2011 ) (to be codified at 17 C.F.R. pts. 229, 232, 240, 249).

${ }^{277}$ See Dodd-Frank Act $\$ 943(1)$; Disclosure for Asset-Backed Securities Required By Section 943 of the Wall Street Reform Consumer Protection Act, 76 Fed. Reg. at 4489.

${ }^{278}$ Specifically, the risk retention requirements may be reduced where the underwriting standards employed by the originator indicate that those assets manifest less credit risk. In addition, these requirements do not apply in respect of ABS collateralized exclusively by certain "qualified residential mortgages." Dodd-Frank Act \$941(b).

${ }^{279}$ See id.

${ }^{280}$ These risk retention requirements must also be viewed in conjunction with Basel III, which, when effective, will impose more conservative capital requirements in respect of some securitization exposures. For an overview of these requirements, see Tougher Capital Requirements Under Basel III Could Raise the Costs of Securitization, STANDard \& PoOr's (Nov. 17, 2010).

${ }^{281}$ The OCC, Federal Reserve Board, FDIC and SEC are responsible for promulgating regulation in respect of the risk retention requirements. The SEC, meanwhile, is responsible for adopting regulation in respect of the disclosure requirements.

${ }^{282}$ Although, as will be explored in greater detail below, there is considerable scope for substantive divergence.

${ }_{283}$ Much like the new U.S. regime, EMIR establishes a process for determining whether an instrument is eligible for centralized clearing. This process can unfold in one of two ways. 
ties" 284 be cleared and settled through a CCP. ${ }^{285}$ This mandatory clearing requirement also applies to non-financial counterparties whose derivatives positions-excluding those objectively linked to the counterparty's commercial activities-exceed a prescribed threshold. ${ }^{286,287}$ Both financial and nonfinancial counterparties entering into OTC derivatives not subject to the mandatory clearing requirement, meanwhile, are required to hold "appropriate and proportionate" 288 capital and ensure that they have put in place appropriate procedures and arrangements to "measure, monitor and mitigate operational and credit risk." 289

EMIR also establishes a uniform authorization requirement for CCPs. ${ }^{290}$ While these CCPs will continue to be registered and supervised at the national level, the Regulation empowers ESMA to develop technical standards and to ensure the uniform and objective application of these standards across the E.U. ${ }^{291}$ To this end, it imposes organizational and conduct of business

The first way is a "bottom-up" process, pursuant to which a CCP applies to the European Securities and Markets Authority (ESMA) for a determination. European Market Infrastructure Regulation, Eur. PARL. Doc. (COM 0484) 4(1) (2010). The second "top-down" process involves ESMA, in conjunction with the European Systemic Risk Board (ESRB), determining that a contract should be subject to the mandatory clearing requirement. EUR. PARL. DOC. (COM 0484) 4(5) (2010).

${ }^{284}$ A financial counterparty is defined as including a bank, investment bank, insurance company; UCITS fund,pension fund, or alternative investment fund manager. Eur. PART. DoC. (COM 0484) 2(6) (2010).

${ }^{285}$ See Eur. PARI. Doc. (COM 0484) 3 (2010).

${ }^{286}$ There are actually two thresholds: an information threshold and a clearing threshold. Non-financial counterparties exceeding the information threshold are required to report the details of any OTC derivatives instrument to a trade repository. See Eur. PARL. DOC. (COM 0484) 6(1), 7(1) (2010). Non-financial counterparties exceeding the clearing threshold are subject to the mandatory clearing requirement. See Eur. PArl. Doc. (COM 0484) 6(1), 7(1) (2010). Instruments that are objectively ascertained to be linked to a non-financial counterparty's commercial activities will not be taken into account in determining whether the counterparty has exceeded the clearing threshold. See Eur. PARI. Doc. (COM 0484) 3(4) (2010). ESMA and the ESRB have been handed primary responsibility for articulating the substance of both thresholds no later than June 30, 2012. See Eur. PART. Doc. (COM 0484) $7(3)(2010)$.

${ }^{287}$ It is not clear on the face of this provision how transactions between a financial and non-financial counterparty not exceeding either the information or clearing tests would be treated. If EMIR is to be consistent with Title VII of the Dodd-Frank Act, however, such transactions should be exempt.

${ }^{288}$ Eur. PARI. DOC. (COM 0484) 8(1) (2010). The European Commission is empowered under EMIR to adopt technical regulation specifying the amount of capital necessary to comply with art. 8(1). See Eur. PARI. Doc. (COM 0484) 8(2) (2010).

${ }^{289}$ Eur. PArL. Doc. (COM 0484) 8(2) (2010).

${ }^{290}$ See Eur. PARt. Doc. (COM 0484) $10(2010)$. CCPs, derivatives exchanges and alternative execution facilities are already subject to E.U. regulation under MiFID. The E.U. has launched a consultation that is seeking to, inter alia, determine how MiFID should be updated to reflect emerging trends in this area. See Press Release, Eur. Union, Financial Services: Improving European Rules for a More Robust Framework for All Financial Actors and Instruments (Dec. 8, 2010), http://europa.eu/rapid/pressReleasesAction.do?reference $=$ IP/10/1677\& format $=$ HTML\&aged $=0 \&$ language $=E N \&$ guilanguage $=E N$.

${ }^{291}$ See Eur. PArl. Doc. (COM 0484) (2010) ("Explanatory Memorandum"). 
requirements on CCPs respecting, inter alia, initial capital; ${ }^{292}$ governance; ${ }^{293}$ ownership; ${ }^{294}$ access; ${ }^{295}$ transparency; ${ }^{296}$ outsourcing; $;{ }^{297}$ segregation; ${ }^{298}$ position portability; ${ }^{299}$ and interoperability. ${ }^{300}$ It also imposes prudential requirements respecting, inter alia, margin and collateral mechanisms; ${ }^{301}$ permitted investments; ${ }^{302}$ default waterfalls, funds, and other procedures; ${ }^{303}$ and risk modeling, stress testing, and back testing. ${ }^{304}$

Lastly, EMIR requires all "trade repositories"305 (TRs) to register with ESMA. ${ }^{306}$ It then subjects this new class of registrants to organizational and operational requirements respecting, inter alia, governance; ${ }^{307}$ access; ${ }^{308}$ information safeguarding; ${ }^{309}$ transparency; ${ }^{310}$ and data availability. ${ }^{311}$ Financial counterparties, along with non-financial counterparties whose derivatives positions exceed a prescribed information threshold, are required to report

${ }^{292}$ All CCPs are required to have permanent, available, and separate capital of at least EUR 5 million. Eur. PARL. DOC. (COM 0484) 12(1) (2010).

${ }^{293}$ Eur. PARI. Doc. (COM 0484) 24-26, 31 (2010). These governance requirements contemplate, among many other matters: (1) clear separation between the reporting lines for risk management and other operations, (2) remuneration policies designed to support sound risk management, (3) frequent and independent audits, and (4) the establishment of an independent risk committee to advise the board of directors on any arrangements that may impact the risk management of the CCP.

294 See Eur. PARI. Doc. (COM 0484) 28 (2010).

${ }^{295}$ See Eur. P^rl. Doc. (COM 0484) 35 (2010). Most importantly, CCPs must establish non-discriminatory, transparent, and objective criteria for ensuring fair and open access to the CCP.

${ }^{296}$ See Eur. PARI. Doc. (COM 0484) 36 (2010). Notably, in certain prescribed circumstances, these requirements empower national regulatory authorities to refuse authorization or "take other appropriate measures" in response to issues surrounding the identity, influence, or holdings of a CCP's owners.

${ }^{297}$ See Eur. PARI. Doc. (COM 0484) 33 (2010).

208 See Elr. Parl. Doc. (COM 0484) 37 (2010).

${ }^{299}$ See id.

${ }^{300}$ See Eur. PArl. Doc. (COM 0484) 48-50 (2010).

${ }^{301}$ See Eur. Pari. Doc. (COM 0484) 39, 43 (2010).

302 See Eur. PArL. Doc. (COM 0484) 44 (2010). These requirements are designed to ensure that a CCP will only invest in highly liquid assets to which it enjoys prompt and nondiscriminatory access.

${ }^{303}$ See Eur. PARt. Doc. (COM 0484) 40, 42, 45 (2010). These requirements prescribe, inter alia, (1) that a CCP shall maintain a fund to cover losses arising from the default of a clearing member, (2) the order in which the financial resources of a CCP shall be deployed in the event of default, and (3) that a CCP shall have in place procedures to be followed in various default scenarios.

${ }^{304}$ See Eur. PARL. DOC. (COM 0484) 46 (2010). Specifically, a CCP must regularly review its models and parameters and subject its models to rigorous and frequent stress tests to evaluate their resilience in extreme but plausible market conditions. It must also perform backtests to evaluate the reliability of the methodology adopted. The results of these tests must be reported to the relevant national authority.

${ }^{305}$ Eur. PARI. Doc. (COM 0484) 10 (2010). TRs are the E.U. equivalent of SDRs under the Dodd-Frank Act.

306 See Eur. PARi. Doc. (COM 0484) 51 (2010).

${ }^{307}$ See Eur. Part. Doc. (COM 0484) 64(1)-(4) (2010).

${ }^{308}$ See Eur. Pari. Doc. (COM 0484) 64(5) (2010).

309 See Eur. PArl. Doc. (COM 0484) 66 (2010).

${ }^{310}$ See Eur. Pari. Doc. (COM 0484) 67 (2010).

311 See id. 
all OTC derivatives transactions to a registered TR. ${ }^{312}$ TRs are in turn required to make this information available to both ESMA and the relevant national authorities and to publicly disclose aggregate derivatives positions broken down by class. ${ }^{313}$

\section{The Post-Crisis Regulatory Response: A Preliminary Assessment}

On the surface, the Dodd-Frank Act and EMIR represent a wholesale shift in terms of the regulation of OTC derivatives markets. But how far do these reforms go in responding to the risks and regulatory challenges stemming from complexity and financial innovation? On at least one level, these reforms can be viewed as holding out considerable promise. The DoddFrank Act and EMIR both introduce mechanisms designed to subsidize the production and dissemination of information for use by both market participants and regulators. CCPs, for example, can be understood as simplifying the complex and constantly evolving network of bilateral derivatives exposures-theoretically making it less costly for end-users, dealers, and regulators to evaluate counterparty credit risk in connection with centrally cleared swaps. ${ }^{314}$ SDRs and TRs, meanwhile, will serve as important nodes for the aggregation and dissemination of derivatives trading data in respect of both centrally and bilaterally cleared instruments. ${ }^{315}$ The enhanced disclosure requirements for ABS and other securitizations under the Dodd-Frank Act are, similarly, a step in the right direction.

Simultaneously, however, considerable work remains to be done to shine a more powerful light on some of the murkier corners of the global financial system. Almost two years after the enactment of the Dodd-Frank Act, the Office of Financial Research-the new federal agency charged with the task of improving the quality of financial information available to U.S. policymakers-has yet to produce any meaningful research or market data. ${ }^{316}$ More fundamentally, finalizing the legislative frameworks governing CCPs, SDRs/TRs and other major market participants has been an extremely

${ }^{312}$ See Eur. Pari. Doc. (COM 0484) 6, 7(1) (2010).

${ }^{313}$ See Eur. PArl. Doc. (COM 0484) 67 (2010).

${ }^{314}$ In effect by transforming a complex 'web' of exposures into a simpler 'hub and spoke' network. See Gai et. al., supra note 25 , at 22-3.

315 Although this will ultimately depend on the type and format (and thus usability) of the information that must be made available to regulators and the public. For a discussion of the relevant issues in this regard, see Requirements for OTC derivatives data reporting and aggregation: CPSS-IOSCO publishes final report, BANK FOR INI'L SETTLEMENTS (Jan. 2012), http:// www.bis.org/publ/cpss100.pdf.

${ }^{316}$ Having produced only one working paper-a survey of existing quantitative measures of systemic risk-and no actual financial data as of April 2012. See Dimitrios Bisias, et al., A Survey of Systemic Risk Analytics (U.S Dep't of the Treasury Office of Fin. Research, Working Paper \#1, 2012), available at http://www.treasury.gov/initiatives/wsr/ofr/Documents/OFRwp0 001_BisiasFloodLoValavanis_ASurveyOfSystemicRiskAnalytics.pdf. 
slow-and often opaque-process in many jurisdictions. ${ }^{317}$ Indeed, the projected timeframes for full implementation of these reforms in the U.S., Europe, and elsewhere (originally slated for December 2012) are now far from clear. ${ }^{31}$ Compounding matters, uneven implementation across jurisdictions-in terms of both timing and substantive content-may actually serve to increase information costs. ${ }^{319}$ While progress has been measurable, we are thus still some distance from realizing the objective of meaningfully reducing information costs within OTC derivatives markets and, ultimately, leveling the informational playing field.

Moreover, while timely and comprehensive access to information is undoubtedly a necessary condition for both optimal private contracting and effective public oversight, it is by no means sufficient. As soberly illustrated by the collapse of the U.S. MBS market in $2007-2008,{ }^{320}$ the subsequent run in the repo market at the epicentre of Lehman's demise, ${ }^{321}$ and Robert Bartlett's event study involving the derivatives disclosures of Ambac Financial, ${ }^{322}$ the sheer volume of information available within modern financial markets-combined with the rapid pace of change-can overwhelm the powerful incentives of even the most sophisticated market participants. Regulators, likewise, have struggled with what is, in effect, information overload. As we have seen, this dense "information thicket" 323 is rendered even more impenetrable by other drivers of complexity including, inter alia, technology, interconnectedness, fragmentation, regulation, and reflexivity. Viewed from this perspective, the marginal benefits of simply generating more information may be very limited indeed.

One intuitively appealing potential policy response-especially if we believe that the complexity of modern financial markets contributes to market failure and other socially suboptimal outcomes-is to enhance the resources, incentives and expertise of public regulators. ${ }^{324}$ Thus, for example,

${ }^{317}$ For an overview of the status of these reforms, see Overview of Progress in the Implementation of the G20 Recommendations for Strengthening Financial Stability, Fin. STABILITY Bр. 2, 16-18 (Nov. 4, 2011), http://www.financialstabilityboard.org/publications/r_111104gg. pdf; OTC Derivatives Market Reforms, Fin. STABILITY BD. (Oct. 11, 2011), http:// www.financialstabilityboard.org/publications/r_111011 b.pdf.

${ }^{318}$ See Overview of Progress in the Implementation of the G20 Recommendations for Strengthening Financial Stability, FIN. STABIt ITY BD. 2, 16-18 (Nov. 4, 2011), http:// www.financialstabilityboard.org/publications/r_111104gg.pdf

${ }^{319}$ And, of course, raises the prospect of regulatory arbitrage.

${ }^{320}$ See Gary Gorton, The Subprime Panic, 15 Eur. Fin. MGMT. 10 (2009); Gorton, supra note 30 .

${ }^{321}$ See Gary Gorton \& Andrew Metrick, Securitized Banking and the Run on Repo (Nat'1 Bureau Econ. Research, Working Paper No. w15223, 2009); GARY GorTon, SI.APPID IN THE FACE by the Invisible HANd: BANking AND the PANIC OF 2007 (2009), available at http:// papers.ssrn.com/sol3/papers.cfm?abstract_id=1401882; Gary Gorton, Information, Liquidity and the (Ongoing) Panic of 2007, (Nat'1 Bureau Econ. Research, Working Paper No. w14649, 2009).

${ }^{322}$ See Bartlett, supra note 31.

${ }^{323} I d$.

${ }^{324}$ At least insofar as the anticipated benefits exceed the marginal costs. 
we can take steps to ensure that front-line supervisory agencies such as the SEC and CFTC are better funded and, as a corollary, that their sources of funding are sufficiently insulated from undue political interference. ${ }^{325} \mathrm{We}$ can also re-examine how we compensate supervisory personnel with a view to both attracting and retaining top talent and better aligning their private incentives with the pursuit of public regulatory objectives. ${ }^{326}$

Lamentably, the trajectory of financial regulation in many jurisdictions appears to be heading in something of the opposite direction. The CFTC's budget, for example, has been under almost constant threat from Congressional Republicans since the Dodd-Frank Act expanded the agency's mandate to include (joint) oversight of OTC derivatives markets. ${ }^{327}$ Moreover, while financial sector compensation practices have figured prominently in the post-crisis debate, ${ }^{328}$ relatively little time or attention has been paid to how we compensate the public regulators who oversee this vast, powerful, and socially important industry. ${ }^{329}$ Given the enormity of the stakes, there exists a strong case for re-evaluating these (and other) decisions in terms of their likely impact on both the capacity and incentives of public regulators to effectively monitor modern financial markets.

Another potential response is to simplify some of the more complex elements of modern financial markets. David Scharfstein and Adi Sunderam, for example, have identified a number of potential options for reducing complexity within U.S. residential mortgage and MBS markets. ${ }^{330}$ These options include: (1) limiting the availability of (or altogether prohibiting) mortgages with "risky" characteristics such as high loan-to-value ratios, self-financed down-payment assistance, adjustable rates or negative amortization; (2) prohibiting the securitization of such risky mortgages; (3) simplifying the

${ }^{325}$ Admittedly, this is more of a problem in the U.S. (where regulators such as the SEC and CFTC rely on Congress for funding) than in the U.K. (where funding is derived principally from industry levies).

${ }^{326}$ Frederick Tung and Todd Henderson, for example, have proposed a compensation structure for bank supervisors, which, inter alia, links their compensation to the value of equity and debt in the banks they oversee. See Frederick Tung \& Todd Henderson, Pay for Regulator Performance 1 (Working Paper, 2012), available at http://papers.ssrn.com/sol3/ papers.cfm?abstract_id $=1986484 \&$ http://papers.ssrn.com/sol3/pa-

pers.cfm?abstract_id=1986484. For a discussion of some of the potential pitfalls of this particular proposal, see $i d$. at $61-70$.

${ }_{327}$ See Shahien Nashiripour, Tight Budget Set for US Markets Regulator, FIN. TIMES (Nov. 16, 2011), http://Www.ft.com/cms/s/0/1 be825ae-0fdd-11e1-a468-00144feabdc0.html\#axzz $1 \mathrm{rNvZdBNd.}$

${ }^{328}$ For a small sampling of this research, see Lucian Bebchuk and Holger Spamann, Regulating Bankers' Pay, 98 GEO. L.J. 247 (2010); Lucian Bebchuk, Alma Cohen \& Holger Spamann, The Wages of Failure: Executive Compensation at Bear Stearns and Lehman 2000-2008, 27 YALE. J. ON REg. 257 (2010); Rüdiger Fahlenbrach \& René Stulz, Bank CEO Incentives and the Credit Crisis, 99 J. FIN. Econ. 11 (2011).

${ }^{329}$ With the notable exception of Tung and Henderson, supra note 326.

${ }^{330}$ See David Scharfstein \& Adi Sunderam, The Economics of Housing Finance Reform: Privatizing, Regulating and Backstopping and Mortgage Markets, The BroOKInGs Inst. (Feb. 2011), http://www.brookings.edu/ /media/Files/events/2011/0211_mortgage_market/0211_ mortgage_markets_scharfstein_sunderam.pdf. 
capital structures that can be used in connection with securitization vehicles; and (4) prohibiting the re-securitization of junior tranches of MBS into CDOs. ${ }^{331}$ An analogous set of measures for bilaterally cleared swaps might conceivably include: (1) restrictions on the types of swaps available to nonfinancial end-users ${ }^{332}$, (2) mandating higher (and higher quality) collateral, ${ }^{333}$ and (3) prohibiting the re-hypothecation of pledged collateral.

Theoretically, regulatory intervention of this kind would serve at least two purposes. ${ }^{334}$ First, restrictions on the availability of risky mortgages or more complex swaps would insulate those with lower tolerances for complexity from the negative consequences of both their own suboptimal decision-making and the sharp practices of more sophisticated financial intermediaries. Second, by simplifying the arcane plumbing of these markets, such measures would reduce information costs for both market participants (investing in swaps, MBS and CDOs and posting or receiving these instruments as collateral) ${ }^{335}$ and regulators (attempting to identify, monitor, and respond to the attendant risks). Ultimately, of course, the welfare implications of Sharfstein and Sunderam's and other similar proposals are difficult to evaluate: while they may serve to reduce information (and agency) costs and promote greater financial stability, one might also expect them to have an adverse impact on both the ability of counterparties to effectively hedge risk $^{336}$ and, more broadly, the flow of credit to the real economy. Indeed, as we have seen, this welfare indeterminacy is itself an important contributing factor to the complexity of modern financial markets.

While the Dodd-Frank Act and EMIR can be seen as representing (at the very least) a marginal improvement over the pre-crisis status quo in terms of responding to the regulatory challenges generated by complexity, these same regimes effectively disregard the challenges arising from the nature and pace of financial innovation. Indeed, in at least one respect, these nascent regimes may actually incentivize socially suboptimal over-innovation. Specifically, the newly created regulatory dichotomy between centrally and bilaterally cleared swaps generates two distinct payoff structures for market participants. This, in turn, invites financial innovation-or, perhaps

331 See id. at $40-45$.

${ }^{332}$ Articulating a clear (and yet un-arbitragable) boundary between permitted and prohibited swaps would obviously be an important and difficult task in connection with the implementation of any such proposal.

${ }^{333}$ Indeed, regulators in both the U.S. and Europe have signaled their desire to impose such requirements in connection with the implementation of the Dodd-Frank Act and EMIR, respectively. See Dodd-Frank Wall Street Reform and Consumer Protection Act, Pub. L. No. 111-203, $\$ 733,763,24$ Stat. 1376 (2010); EMIR art. 35.

334 In addition to the enhanced financial stability posited by Scharfstein and Sunderam. See Scharistian \& Sundiram, supra note 330.

335 Thus potentially ameliorating the adverse selection problem, which triggered the run on repo. See Gorton \& Metrick, supra note 321.

${ }^{336}$ At least in the case of bilaterally cleared swaps. 
more accurately, "faux customization" 337 - motivated by the desire to avoid the marginal costs associated with central clearing. Ultimately, there are any number of reasons why dealers or other counterparties might find it more advantageous to utilize bilateral instruments (even after accounting for higher margin and capital requirements). Post-crisis constraints on the supply of high quality collateral, for example, have increased the opportunity costs of central clearing relative to the (often under-collateralized ${ }^{338}$ ) bilateral market. ${ }^{339}$ Along a similar vein, moving standardized instruments on to CCPs will require dealers to unbundle netted positions involving both standardized and non-standardized instruments. ${ }^{340}$ In the end, these collateral and netting benefits may prove very substantial indeed.

The prospect of faux customization is rendered even more acute by virtue of the fact that, at present, OTC derivatives dealers enjoy effective control over the CCPs which, in the vast majority of cases, will make the initial determinations in terms of a swap's eligibility for central clearing. ${ }^{341}$ As Sean Griffith explains: "major dealers have an incentive to exert governance control to keep clearing eligible products off of clearinghouses so that they can continue to trade in the higher margin bilateral market." 342 Importantly in this regard, neither the Dodd-Frank Act nor EMIR mandate regulatory review of a CCP's decision that an instrument is ineligible for central clearing. Compounding matters, one might expect regulators to be reluctant to overturn a CCP's eligibility determination out of concern that forcing instruments on to CCPs could exacerbate systemic risk. ${ }^{343}$ Indeed, this reluctance might be reinforced by asymmetries of information and expertise vis-à-vis regulators and CCPs. In this respect, there appears to be ample room for improvement in terms of how the Dodd-Frank Act and EMIR address these information and incentive problems.

One possible way of addressing the problem of faux customization would be to impose a targeted anti-arbitrage rule (or TAAR) on swap dealers and other market participants. The primary thrust of a TAAR would be to mandate that market participants obtain regulatory approval as a pre-condi-

\footnotetext{
${ }^{337}$ See Sean Griffith, Governing Systemic Risk: Toward a Governance Structure for Derivatives Clearinghouses, 61 EMORY L. J. 1153, 1197 (2012).

${ }^{338}$ It is at present unclear whether the margin requirements contemplated under either the Dodd-Frank Act or EMIR would eliminate this arbitrage opportunity.

${ }^{339}$ See Manmohan Singh and James Aitken, Deleveraging post Lehman-Evidence from Reduced Rehypothecation (Int'l Monetary Fund, Working Paper 09/42, 2009), available at http://www.imf.org/external/pubs/ft/wp/2009/wp0942.pdf; Singh, supra note 230, at 3-4; Tracy Alloway, Financial System Creaks as Loan Lubricant Dries Up, Fin. TImes (Nov. 28, 2011), http://www.ft.com/intl/cms/s/0/638fe5de-19c1-1 le1-ba5d-00144feabdc0.html\#axzz1r NvZdBNd.

${ }^{340}$ See Singh, supra note 230 , at 4,8 .

${ }^{341}$ Both directly through their equity interests in CCPs and indirectly through their ability to re-route order flow. See Sean Griffith, Incentive Problems in Derivatives Trading: Towards a New Governance Structure for Clearinghouses 24-25 (Working Paper, 2010).

${ }^{342} I d$. at 23 .

${ }^{343}$ See id.
} 
tion to entering into any "new" or "innovative" species of bilateral swap. ${ }^{344}$ In order to obtain this approval, the market participant(s) submitting the application would need to demonstrate that the innovation responded to a legitimate economic need and not simply the desire to avoid central clearing requirements. To minimize the duplication of effort and expense, the relevant regulatory authority could then issue "blanket" orders authorizing all other market participants within their jurisdiction to trade in the new instrument.

A well-designed TAAR would offer two potential benefits. First, it would alter the anticipated payoffs from regulatory arbitrage: in effect deterring financial innovation not motivated by a legitimate economic rationale. ${ }^{345}$ Second, it would provide an incentive for risk adverse market participants to bring new bilateral instruments to the attention of regulators with a view to obtaining "pre-clearance" for their prospective use. A TAAR would thus manifest potentially significant informational benefits-bringing new innovations within the perimeter of regulation more rapidly than would otherwise be the case-while simultaneously reducing the deleterious systemic effects of regulatory arbitrage..$^{346}$

Ultimately, the objective of this paper is not to exhaustively canvas the ways in which regulators might better respond to the challenges posed by complexity and financial innovation. Rather, it has been to punctuate the fact that by simply acknowledging the complexity of modern financial markets and the nature and pace of financial innovation we can potentially gain a more complete and nuanced understanding of the problems we face and, hopefully, how we might go about addressing them. In this respect, this paper should be understood as aspiring to build the foundations for a broader research agenda examining complexity, innovation and the regulation of modern financial markets.

\section{Conclusion}

Complexity and innovation define modern financial markets. Together, they also generate a host of pressing regulatory challenges. As we have seen,

\footnotetext{
${ }^{344}$ What precisely constituted a "new" or "innovative" swap would of course need to be fleshed out. Here, however, the definition of innovation introduced supra Part III-focusing as it does on change as opposed to improvement-would arguably provide a very useful starting point.

345 The question of how to distinguish between faux customization and economically "legitimate" innovation would of course be of central importance in terms of the operation of a TAAR. The key for the present purposes, however, is that the burden of proof in this regard would be on the market participant(s) making the application.

${ }^{346}$ Ultimately, of course, further analysis is required to ascertain both the feasibility and desirability of a TAAR. For a critical analysis of the prospective costs and benefits of a General Anti-Avoidance Rule (or GAAR) in the tax context, see Graham Aaronson QC, A Study to Consider Whether $\Lambda$ General Anti-avoidance Rule Should be Introduced into тнг: U.K. TAX SystTM, (The GAAR Study Group 2011), available at http://www.hmtreasury.gov.uk/tax_avoidance_gaar.htm.
} 
these challenges stem from high information costs, deeply entrenched asymmetries of information and expertise, and the acute agency cost problems these asymmetries generate. These challenges underscore the necessity (if not sufficiency) of mechanisms such as CCPs and SDRs/TRs that subsidize the production and dissemination of information as a means of promoting both more efficient private contracting and more effective public oversight. They also potentially justify more radical regulatory intervention with a view to reducing complexity within some of the more arcane corners of the global financial system. Simultaneously, these challenges point to the desirability of regulation capable of responding to the inherent dynamism of modern financial markets and, more specifically, the nature and pace of financial innovation. Here, measures such as a well-designed TAAR for bilateral swap markets could potentially help reveal valuable information and deter socially questionable forms of innovation. In the end, while recent regulatory reforms under the Dodd-Frank Act and EMIR have arguably gone some distance in addressing these challenges, considerably more work thus remains to be done before modern financial markets begin to resemble the perfect markets envisioned by conventional financial theory. 